\title{
Copper-Catalysed C-H Functionalisation gives access to 2-aminobenzimidazoles
}

\author{
Peter R. Clark ${ }^{\star a, b}$, Glynn D. Williams ${ }^{a}$, Nicholas C. O. Tomkinson ${ }^{b}$
}

This paper describes the development, optimisation and exemplification of a copper-catalysed $\mathrm{C}-\mathrm{H}$ functionalisation to form pharmaceutically relevant 2-aminobenzimidazoles from aryl-guanidines. High throughput screening was used as a tool to identify a catalytically active copper source, DoE was used for reaction optimisation and a range of arylguanidines were prepared and exposed to the optimum conditions to afford a range of 2-aminobenzimidazoles in moderate to good yields. The methodology has been applied to the synthesis of Emedastine, a marketed antihistamine pharmaceutical compound, with the key cyclisation step performed on a gram-scale.

\section{Introduction}

The direct functionalisation of aryl $\mathrm{C}-\mathrm{H}$ bonds to form heterocycles presents the synthetic chemist with a powerful method which overcomes the prelimitations encountered with more traditional approaches. ${ }^{1}$ In recent years there has been a significant focus towards developing robust methodologies which target the synthesis of pharmaceutically relevant heterocycles through a $\mathrm{C}-\mathrm{H}$ functionalisation approach. ${ }^{2-5}$

One of the major challenges with a transition-metal catalysed $\mathrm{C}-\mathrm{H}$ functionalisation is the requirement for an external oxidant to be present to facilitate catalyst turnover. As such, there is an emerging interest in developing reactions which utilise the oxidative capacity of molecular oxygen as the terminal oxidant, owing to the environmental and practical benefits with using air as a reagent. ${ }^{6-9}$ For example, seminal work by the Buchwald group in $2008^{10}$ described the synthesis of benzimidazoles directly from aryl-amidines using a copper(II) source in the presence of acetic acid under an oxygen atmosphere (Scheme 1). This reaction class highlighted the potential for simple, unfunctionalised starting materials to be efficiently and effectively manipulated into important pharmaceutical building blocks.

Scheme 1. Benzimidazoles from aryl-amidines.

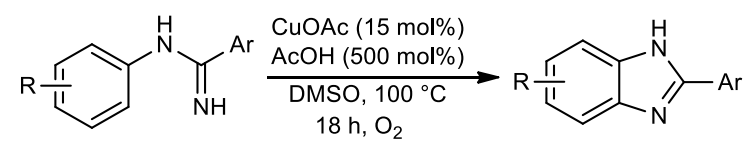

2-Amino benzimidazoles represent an important class of heterocycle due to their antibacterial, ${ }^{11}$ immunosupressive, ${ }^{12}$ antidiabetic, ${ }^{13}$ antiviral ${ }^{14}$ and analgesic ${ }^{15,16}$ properties. For example, their use in the treatment and prevention of parasitic worm infections (Albendazole 1) and prevalence in second generation antihistamines (Emedastine 2, Figure 1) highlight this. Given the importance of this heterocycle, it was therefore surprising that a $\mathrm{C}-\mathrm{H}$ functionalisation strategy which exploits atmospheric oxygen as a terminal oxidant has not been reported for the synthesis of 2-amino benzimidazoles.

Figure 1. Emedastine and Albendazole: Important 2-aminobenzimidazoles.

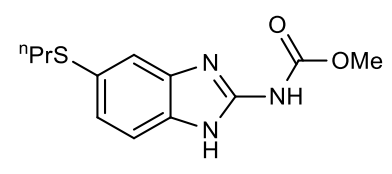

Albendazole, 1

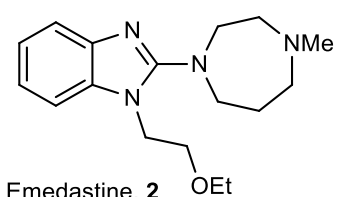

Emedastine, 2 OEt

2-Aminobenzimidazole is a commercial material, which itself presents opportunities to probe molecular space through substitution on the carbon skeleton on either of the endocyclic or exocyclic nitrogen atoms. Direct alkylation of this substrate with dimethylsulfate furnishes a mixture of compounds baring varying degrees of alkylation on all three nitrogen atoms. ${ }^{17}$ This highlights how using this heterocycle as a feedstock for developing new classes of compounds is challenging. Therefore, several methods have been developed for the synthesis of this specific heterocycle (Scheme 2). One of the simplest retrosynthetic disconnections to form this class of compound is an $S_{N} A r$ reaction of 2-chlorobenzimidazole 3 with an amine (Method A, Scheme 2a). This has been shown to furnish 2- 
aminobenzimidazoles, ${ }^{18}$ however, the preparation of 2-chlorobenzimidazole represents an additional non-trivial synthetic challenge. Other methods to prepare 2-aminobenzimidazoles require the use of super-stoichiometric mercury salts for the ring-closing of thiourea derivatives from 1,2-diaminobenzenes (Method B Scheme 2a). ${ }^{19,20}$ Whilst effective, this method has low atom-economy \& utilises mercury which reduces the feasibility of these reactions, particularly within larger scale synthesis. Consequently, the starting materials for these reactions all bare 1,2-diamine substitution on the arene scaffold, which are often unstable or require pre-preparation. ${ }^{21}$ Methods which avoid the use of 1,2-diaminobenzenes have been reported, ${ }^{22}$ which employ 1,2-dihaloarenes (Method C, Scheme 2a) whose preparation again represents a significant challenge in itself. Despite these methods, there remains a clear, unmet need for direct heterocycle synthesis from readily available feed-stock materials which take advantage of contemporary $\mathrm{C}-\mathrm{H}$ amination strategies in a more sustainable manner. Efforts towards this have been achieved with a direct $\mathrm{C}-\mathrm{H}$ amination reported by Zhang et al using hypervalent iodine-based oxidants (Method D, Scheme $2 \mathrm{a})^{23}$, however, these hypervalent iodine-based oxidants are relatively expensive and produce undesirable waste streams. The ideal oxidant would need to be cheap, easy to handle and produce minimal waste.

With these observations in mind, we envisaged that modification of the conditions reported by Buchwald in $2008^{10}$ (Scheme 1) could allow access to this privileged heterocycle through the use of a guanidine starting material. In addition, the transformation would use oxygen as the terminal oxidant (Figure 2b). Within this paper we describe the development of an optimised process for the synthesis of 2-aminobenzimidazoles with robust conditions and apply a range of aryl-guanidines to these conditions. We also discuss some mechanistic experimentation and the preparation of the antihistamine, Emedastine (2), on gram scale.

Scheme 2: Current synthetic approaches and the proposed aerobic $\mathrm{C}-\mathrm{H}$ functionalisation to 2amionobenzimidazoles

a) Current synthetic approaches

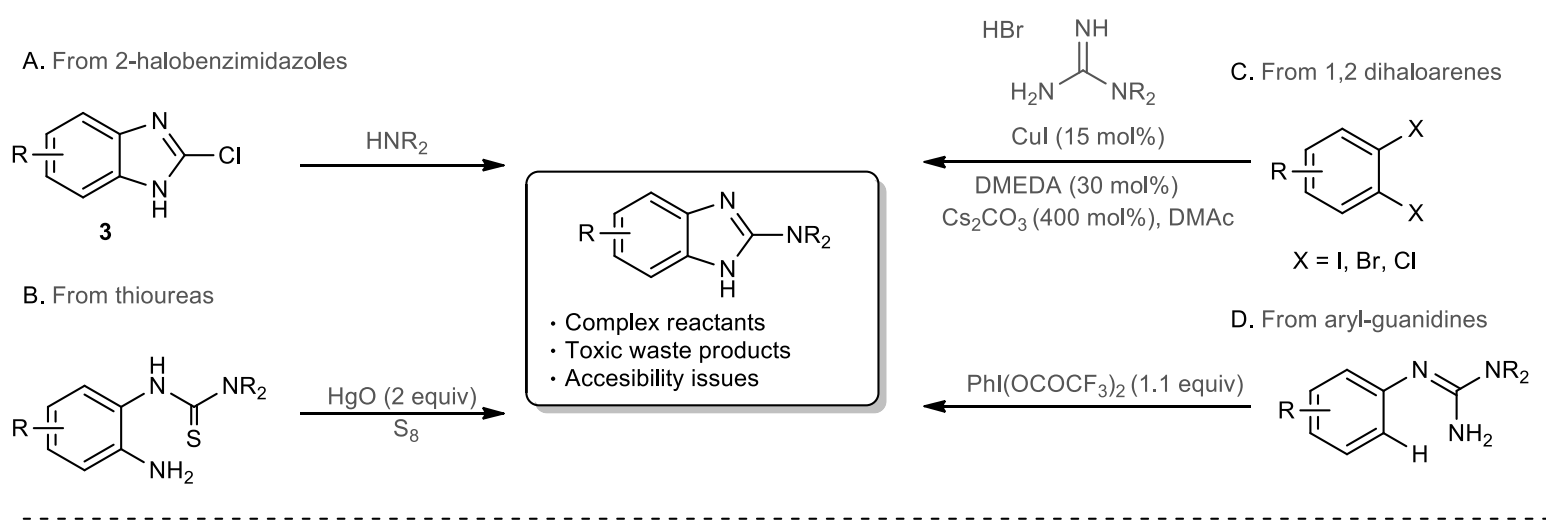

b) This work: Aerobic 2-aminobenzimidazole synthesis from aryl-guanidines

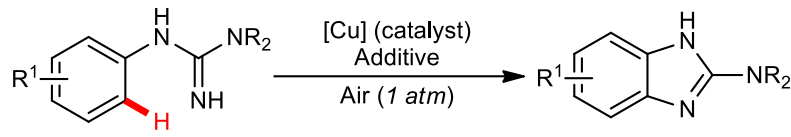

\section{Results and discussion}

At the outset of our studies we sought to optimise the cyclisation of $\mathbf{4}$ to aminobenzimidazole $\mathbf{5}$. A high throughput screen consisting of 82 reactions examining catalyst, solvent and additives was conducted under 6 bar of air. The elevated pressure for this screen was chosen to increase the gas solubility in the solvents and reduce the variability that is often associated with poor mixing in a two-phase system. Using the conditions reported by Buchwald (Entry 1 Table 1) gave $8 \%$ benzimidazole 5 with $73 \% 4$ remaining. ${ }^{10} \mathrm{Next}$, the amount of acetic acid could be lowered to 1 equivalent (Entry 2) without a decrease in yield (8\%). Changing to pivalic acid as the additive (Entry 3 ) gave an increase in benzimidazole formation (15\%). Copper(I) acetate proved to be more effective than copper(II) acetate (Entry 4, 31\%). We next examined alternative solvents in our optimisation process. Our selection criteria for this necessitated that we considered solvents with high flashpoints to minimise any risk associated with heating 
flammable materials in an oxidative atmosphere (see the Supporting Information for full details). NMP provided $41 \%$ product with $14 \%$ starting material remaining by HPLC analysis with $15 \%$ catalyst loading at $100{ }^{\circ} \mathrm{C}$ (Entry 5 ). The major side product of the transformation was dimeric species $6(10 \%)$. Lowering the temperature to $80^{\circ} \mathrm{C}$ significantly reduced the quantity of this impurity (Entry $6,2 \%$ ) whilst maintaining the yield of $5(35 \%)$. The production of the dimeric species increased with the amount of copper used, resulting in lower amounts of the desired product $\mathbf{5}$ being observed at higher copper loadings (Entries $6-8$ ), with up to $25 \%$ of the dimer observed when using one equivalent of copper(I) acetate (Entry 8). We postulated that removing oxygen from the reaction media would disfavour the formation of this dimeric species as the product likely forms from a second oxidation event. When one equivalent of copper $(\mathrm{I})$ acetate was used in freeze-pump-thawed NMP under inert conditions, we isolated $64 \%$ of the product 5 after 21 hours, with no formation of $\mathbf{6}$ detected by HPLC analysis of the reaction mixture (Entry 9). Despite this encouraging result, we were interested in the possibility of achieving a catalytic cyclisation \& pursued further optimisation.

Owing to the propensity of the reaction to form dimeric benzimidazole 6 when using a catalytic quantity of copper(I) acetate, we examined alternative copper sources. High through-put screening of precomplexed copper sources, additives and solvents was performed (see Supporting Information for full details). Changing the solvent from NMP to sulfolane (Entry 10) delivered $45 \% 5$ with $30 \%$ aryl-guanidine starting material remaining (cf. Entry $7,42 \% \mathbf{5}, 15 \%$ aryl-guanidine). Interestingly this also led to significantly reduced quantities of the dimeric species 6 (5\%). Using copper(II) ethyl acetoacetate (EAA, Entry 11, 54\% 5) proved advantageous over copper(I) acetate and changing pivalic acid for acetic acid (Entry 12) delivered reduced quantities of 5 (54\% vs 49\%). Entries 13-14 highlight how the use of sulfolane is beneficial when compared to NMP or DMSO. Electron withdrawing 1,3-dicarbonyl ligands (hexafluoro acetylacetonate, acacF $\mathrm{F}_{6}$ ) proved significantly less effective in promoting the desired transformation (Entry $15,17 \% 5)$. Importantly, use of acetoacetate ligands also reduce the amount of dimer $6(<2 \%)$. Although the precise reason for this observation is unclear, we propose that acetoacetate ligands restrict coordination of multiple benzimidazole species to the catalyst. Alternatively, it is also possible that the ligand promotes decomplexation of the product from the catalyst, thus preventing dimerisation from occurring.

Table 1. Catalyst and solvent determination

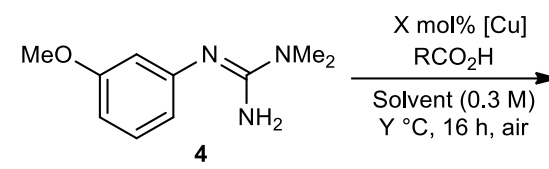<smiles>COc1ccc2[nH]c(N(C)C)nc2c1</smiles><smiles>CNc1nc2cc(OC)ccc2n1-c1cc2[nH]c(N(C)C)nc2cc1OC</smiles>

\begin{tabular}{|c|c|c|c|c|}
\hline Entry & $\begin{array}{l}\text { Copper } \\
\text { source }\end{array}$ & Acid & & Solven \\
\hline 1 & CuOAc2 & $\begin{array}{l}\mathrm{AcOH} \\
\text { equiv) }\end{array}$ & (5 & DMSO \\
\hline 2 & $\mathrm{CuOAc}_{2}$ & $\begin{array}{l}\text { AcOH } \\
\text { equiv) }\end{array}$ & $(1$ & DMSO \\
\hline 3 & $\mathrm{CuOAc}_{2}$ & $\begin{array}{l}\text { PivOH } \\
\text { equiv) }\end{array}$ & $(1$ & DMSO \\
\hline 4 & CuOAc & $\begin{array}{l}\text { PivOH } \\
\text { equiv) }\end{array}$ & $(1$ & DMSO \\
\hline 5 & CuOAc & $\begin{array}{l}\text { PivOH } \\
\text { equiv) }\end{array}$ & $(1$ & NMP \\
\hline 6 & CuOAc & $\begin{array}{l}\text { PivOH } \\
\text { equiv) }\end{array}$ & $(1$ & NMP \\
\hline 7 & CuOAc & $\begin{array}{l}\text { PivOH } \\
\text { equiv) }\end{array}$ & $(1$ & NMP \\
\hline
\end{tabular}

\begin{tabular}{l|l|l|l|}
$\begin{array}{l}\mathrm{X} \\
\mathrm{mol} \\
\%\end{array}$ & $\begin{array}{l}\text { Y } / \\
\%\end{array}$ & \multicolumn{3}{|l|}{$\mathrm{C}$ Conversion } & $6^{*}$ \\
\hline $15 \%$ & $100{ }^{\circ} \mathrm{C}$ & $8 \%(73 \%)$ & $0 \%$ \\
$15 \%$ & $100{ }^{\circ} \mathrm{C}$ & $8 \%(66 \%)$ & $0 \%$ \\
$15 \%$ & $100{ }^{\circ} \mathrm{C}$ & $13 \%(53 \%)$ & $0 \%$ \\
$15 \%$ & $100{ }^{\circ} \mathrm{C}$ & $31 \%(38 \%)$ & - \\
$15 \%$ & $100{ }^{\circ} \mathrm{C}$ & $41 \%(14 \%)$ & $10 \%$ \\
$15 \%$ & $80{ }^{\circ} \mathrm{C}$ & $35 \%(47 \%)$ & $2 \%$ \\
$50 \%$ & $80{ }^{\circ} \mathrm{C}$ & $33 \%(25 \%)$ & $13 \%$
\end{tabular}




\begin{tabular}{|c|c|c|c|c|c|c|c|c|}
\hline 8 & CuOAc & $\mathrm{PivOH}$ & $(1$ & NMP & 100 & $80^{\circ} \mathrm{C}$ & $20 \%(5 \%)$ & $25 \%$ \\
\hline $9^{a, b}$ & CuOAc & $\begin{array}{l}\text { PivOH } \\
\text { equiv) }\end{array}$ & $(1$ & NMP & $\begin{array}{l}100 \\
\%\end{array}$ & $80^{\circ} \mathrm{C}$ & $\begin{array}{l}80 \%, \quad 64 \%^{c} \\
(10 \%)\end{array}$ & $0 \%$ \\
\hline 10 & $\mathrm{CuOAc}$ & $\begin{array}{l}\text { PivOH } \\
\text { equiv) }\end{array}$ & $(1$ & Sulfolane & $50 \%$ & $80^{\circ} \mathrm{C}$ & $45 \%(30 \%)$ & $5 \%$ \\
\hline 11 & $\mathrm{Cu}(\mathrm{EAA})_{2}$ & $\begin{array}{l}\text { PivOH } \\
\text { equiv) }\end{array}$ & $(1$ & Sulfolane & $50 \%$ & $80^{\circ} \mathrm{C}$ & $54 \%(25 \%)$ & $2 \%$ \\
\hline 12 & $\mathrm{Cu}(\mathrm{EAA})_{2}$ & $\begin{array}{l}\text { AcOH } \\
\text { equiv) }\end{array}$ & $(1$ & Sulfolane & $50 \%$ & $80^{\circ} \mathrm{C}$ & $49 \%(31 \%)$ & $2 \%$ \\
\hline 13 & $\mathrm{Cu}(\mathrm{EAA})_{2}$ & $\begin{array}{l}\text { PivOH } \\
\text { equiv) }\end{array}$ & $(1$ & NMP & $50 \%$ & $80^{\circ} \mathrm{C}$ & $43 \%(10 \%)$ & $<1 \%$ \\
\hline 14 & $\mathrm{Cu}(\mathrm{EAA})_{2}$ & $\begin{array}{l}\text { PivOH } \\
\text { equiv) }\end{array}$ & $(1$ & DMSO & $50 \%$ & $80^{\circ} \mathrm{C}$ & $32 \%(41 \%)$ & $0 \%$ \\
\hline 15 & $\mathrm{Cu}_{2}\left(\mathrm{acacF}_{6}\right)$ & $\begin{array}{l}\text { PivOH } \\
\text { equiv) }\end{array}$ & $(1$ & Sulfolane & $50 \%$ & $80^{\circ} \mathrm{C}$ & $17 \%(68 \%)$ & $<1 \%$ \\
\hline
\end{tabular}

All reactions run at 6 bar pressure of air in Cat96 pressure reactor, except entry 9 which was performed inerted in a Shlenk flask.

${ }^{*} H P L C$ peak area\%. Yield in paranthesis refers to amount of starting material remaining (HPLC area). a21 $\mathrm{h}$ reaction time. bfreeze-pump-thaw degassed NMP under nitrogen atmosphere in a Schlenk flask. cisolated yield after chromatography.

$E A A=$ ethyl acetoacetate, $a c a c F_{6}=$ hexafluoro acetylacetonate

From here we sought to further optimise this reaction using electron deficient species 7 as the $\mathrm{C}-\mathrm{H}$ activation step has been described as being slower for electron deficient species,,$^{10}$ and so optimisation of a more challenging trifluoromethyl substrate (7) was pursued. Having observed a significant increase in conversion of 4 using $\mathrm{Cu}(\mathrm{EAA})_{2}$, sulfolane and pivalic acid (table 1), we next switched to open-flask conditions - as opposed to using a high-pressure of air - going forward with our optimisation. This would make the presented chemistry significantly more accessible. Statistical optimisation using design of experiments (DoE) examining concentration, catalyst loading, temperature and pivalic acid loading was performed. These experiments were conducted at atmospheric pressure under open flask conditions using the same equipment, stirring speed \& reaction volume to minimise any difference in mass-transfer of air to the system. Table 2 presents the experimental conditions and results observed by HPLC analysis after a reaction time of 4 hours. $\dagger$

A statistically significant model $\left(R^{2}=0.9735\right)$ was used to generate a half-normal plot (see Supporting Information) to determine the most important parameters for product formation. From this plot we saw that maximising the loading of copper provides the most significant effect on the reaction outcome. The most forcing conditions (Entries 2 and 4 , Table 2) used $25 \mathrm{~mol} \%$ copper at $130^{\circ} \mathrm{C}$ for 4 hours to give $74 \%$ conversion to product. However, the same reactions at 21 hours afforded the product in $52 \%$ and $32 \%$ conversion respectively, indicating that under these conditions the product is unstable. Lowering the temperature to $100{ }^{\circ} \mathrm{C}$ (Entry 8 ) afforded $67 \%$ of the product after 4 hours and $80 \%$ after $21 \mathrm{~h}$, indicating that the product is more stable at lower temperatures. With these observations in mind, we sought to validate this result and isolated $54 \%$ of the product 8 after column chromatography using the conditions shown in Entry $8\left(0.4 \mathrm{M}, 1\right.$ equiv PivOH, $25 \mathrm{~mol} \%$ catalyst, $\left.100^{\circ} \mathrm{C}, 24 \mathrm{~h}\right)$. It is worth noting that despite entries 6 and 9 provide the highest yield at 4 hours, entry 8 provided a higher yield $(80 \%)$ at longer reaction times $(24 \mathrm{~h})$. 
Table 2: Design of Experiments optimisation.

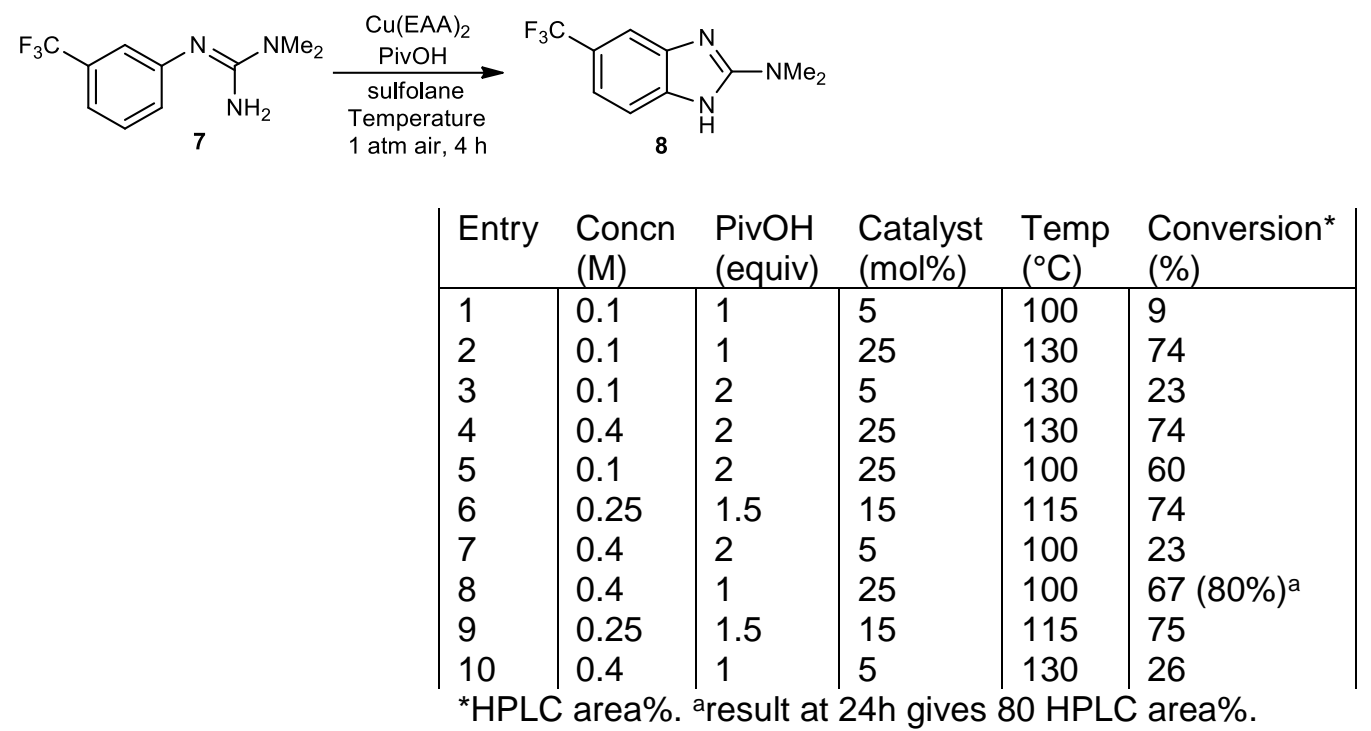

Having optimised the reaction conditions, we prepared a series of $\mathrm{N}, \mathrm{N}$-dialkyl aryl-guanidines by addition of an aniline derivative to easily accessible cyamides (Scheme 3 ). The isolated guanidines were then reacted under our optimised reaction conditions. We were pleased to discover that a range of functional groups were tolerated in the transformation, including esters $(\mathbf{1 1}, \mathbf{1 2})$, nitriles (13) and halogens (14-18) which could be used in subsequent transformations. It is interesting to note the tolerance of halogens on the arene backbone, in particular bromine, as this shows the $\mathrm{C}-\mathrm{H}$ functionalisation event is favoured over Ullmann-type insertion of copper into the carbon-halogen bond under the reaction conditions. ${ }^{24}$ We were unable to detect debromination of meta or para substituted bromines of either product or starting material under the reaction conditions. Products derived from meta-substituted arylguanidines delivered mixtures of regioisomeric benzimidazole products (15-20). Products 15:16 were obtained in a $3: 1$ ratio (35\% combined and isolated), whilst products $17: 18$ were obtained in a $4: 1$ ratio $(90 \%$ combined and isolated). We attributed this change to the size and steric bulk of the different halogen atoms in the substrates. It is worth noting product $\mathbf{8}$ was obtained as a single regioisomer, presumably due to the increased size of a trifluoromethyl group over that of a chlorine or bromine, which disfavours insertion into the proton ortho to the $\mathrm{CF}_{3}$ group. On considering products 19:20, a switch in selectivity to the more hindered position was observed in a 2:5 ratio. Nagasawa et $a^{/ 5}$ reported directed $\mathrm{C}-\mathrm{H}$ insertions by copper to form benzoxazoles, suggesting the direction into a hindered aryl $\mathrm{C}-\mathrm{H}$ bond is facilitated by meta-substituted directing groups. In the case of 19-20, we suspect the switch in selectivity is driven by a directed $\mathrm{C}-\mathrm{H}$ insertion by the pendant dioxole group into the more sterically hindered position.

A range of commercial cyanamides were also used to prepare benzimidazoles 21-25 in moderate to good yields which suggests $\mathrm{N}, \mathrm{N}$-dialkylcyanamides will provide effective substrates for the transformation. It is worth noting that product 26 was not observed under the optimised reaction conditions. The observed product was the debrominated benzimidazole 24, presumably formed by oxidative addition of copper into the ortho $\mathrm{C}-\mathrm{Br}$ bond (as opposed to insertion into the ortho $\mathrm{C}-\mathrm{H}$ bond) and reductive elimination of the product, such as previously reported by Evindar et al. ${ }^{25}$ Other 7-substituted benzimidazole products derived for an ortho-aniline were successfully formed (9). 
Scheme 3: Substrate scope of the developed cyclisation strategy

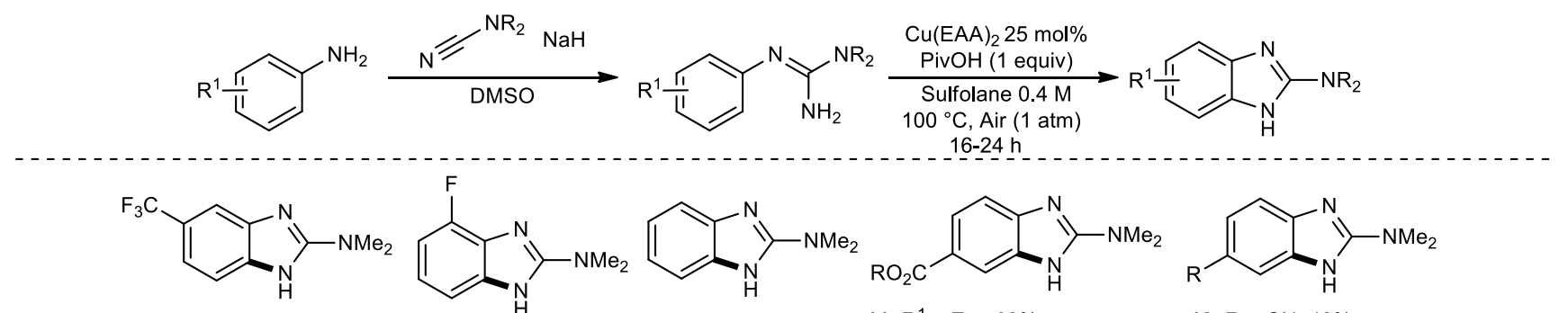

$8,54 \%$

9, $46 \%$

$10,65 \%$

$11, R^{1}=E t, \quad 63 \%$

$12, R^{1}={ }^{\mathrm{t}} \mathrm{Bu}, 53 \%$<smiles>CNc1nc2cc(Cl)ccc2[nH]1</smiles>

$15: 16,35 \%, 3: 1^{*}$<smiles></smiles>

$17: 18,90 \%{ }^{\mathrm{a}}, 4: 1^{*}$<smiles></smiles>

$\langle\overbrace{N}^{\mathrm{N}}\rangle-\mathrm{NMe}_{2}$<smiles>CNc1nc2ccc3c(c2[nH]1)OCO3</smiles>

$19: 20,81 \%, 2: 5^{*}$<smiles>CCNc1nc2ccccc2[nH]1</smiles>

21, $46 \%$<smiles>CCNc1nc2ccc(Br)cc2[nH]1</smiles>

22, $74 \%$<smiles>[X]C1CCN(c2nc3ccccc3[nH]2)CC1</smiles>

23, $\mathrm{X}=\mathrm{CH}_{2}, 41 \%$ $24, X=0,52 \%$<smiles>Brc1ccc2nc(N3CCOCC3)[nH]c2c1</smiles>

$25,59 \%$<smiles>Brc1cccc2nc(N3CCOCC3)[nH]c12</smiles>

26, $0 \%$

*relative HPLC peak areas of crude reaction mixture. Regioisomers (15-20) separated by chromatography and quoted yield is combined isolated yield. aProduct 18 was isolated as an impure mixture of unknown impurities, however the regiochemistry was determined from this isolated material.

\section{Mechanistic studies}

Previous work to understand the formation of benzimidazoles from amidines proposed a number of potential pathways, two of which are presented in Figure 2. ${ }^{10}$ Pathway A involves an SEAr-type addition of the arene onto the guanidyl unit, akin to an electrophillic source of nitrogen, liberating a reduced copper species and forms the product benzimidazole after rearomatisation. Pathway B involves attack of the arene onto the copper centre to form a 6membered organometallocycle, which, after re-aromatisation, reductive elimination and subsequent reoxidation of the copper closes the catalytic cycle and forms the product. More recently a third potential pathway, involving the formation of a copper-nitrene intermediate has been ruled out computationally by Fu et al. ${ }^{26}$

Figure 2. Previously proposed mechanistic pathways

Mechanistic pathways $A$ and $B$<smiles>[R]C(=O)OC[Al]NC([R])=Nc1ccccc1</smiles>

Through measurement of the initial rate of consumption of arylguanidine $\mathbf{2 7}$ and deuterated variant $\mathbf{2 8}$ we observed a small kinetic isotope effect of 1.4 (Scheme 4). This small kinetic isotope effect lies on the boundary between primary and secondary effects, indicating that the cleavage of the $\mathrm{C}-\mathrm{H}$ bond is unlikely to be fully rate-determining; however, this result cannot rule out the possibility of a fourth potential mechanism occurring, involving a concerted metalationdeprotonation event (CMD). ${ }^{26}$ To examine the potential for a CMD mechanism, we performed a screen of different acids examining steric and electronic effects and found no acid surpassed the yield obtained with pivalic acid. $\dagger$ 
Scheme 4. Kinetic isotope effect

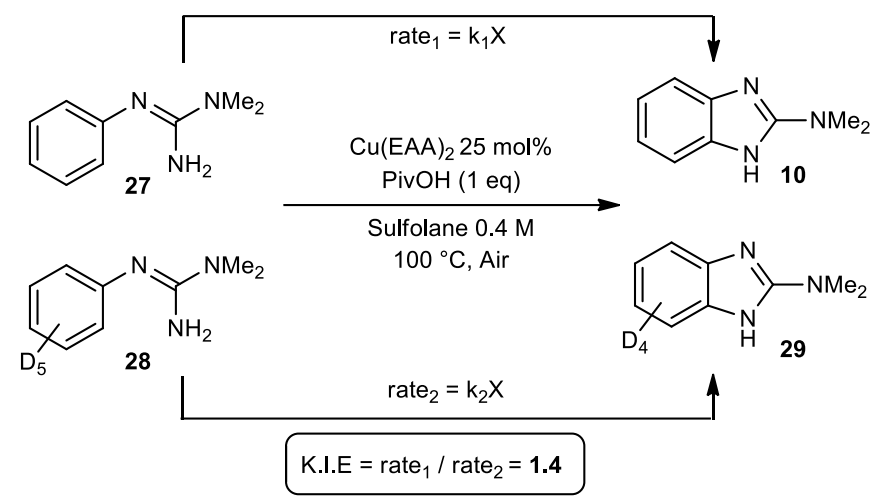

On exposure of $N$-methyl and $N$-benzyl guanidyl derivatives ( $32 \& 33$ Figure 3 ) in which the $N$-alkylbenzimidazole product was expected to be a more labile ligand (owing to the absence of an exchangeable $\mathrm{N}-\mathrm{H}$ in the product benzimidazole), we observed marked decomposition of the substrate with negligible product formation. This could imply that stabilisation of the guanidyl-copper intermediate $\mathbf{3 4}$ is important owing to the presence of multiple tautomeric forms (which is less favourable when $R \neq H$ ). This result could further indicate that coordination of the aniline nitrogen to the copper catalyst is a key artefact of the mechanistic cycle which is inhibited by alkylating this position (Figure 3a). Secondly, this could indicate that reductive elimination from an $\mathrm{sp}^{3}$ nitrogen is more favourable when compared to the $\mathrm{sp}^{2}$ alternative (Figure $3 \mathrm{~b}$. A final mechanistic point to note is that we observed the formation of peroxide during the reaction by use of an enzymatic peroxide detection kit. This is presumably formed as the byproduct of oxidation with air.

Figure 3. $N$-capped aryl-guanidines

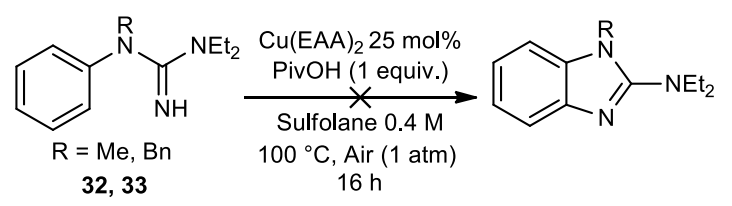

(a) Stabilisation of guanidyl-copper intermediate

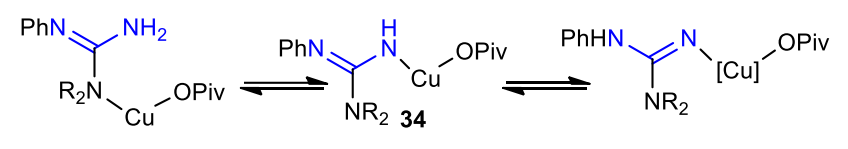

(b) Disfavoured reductive elimination from $\mathrm{sp}^{2}$ nitrogen

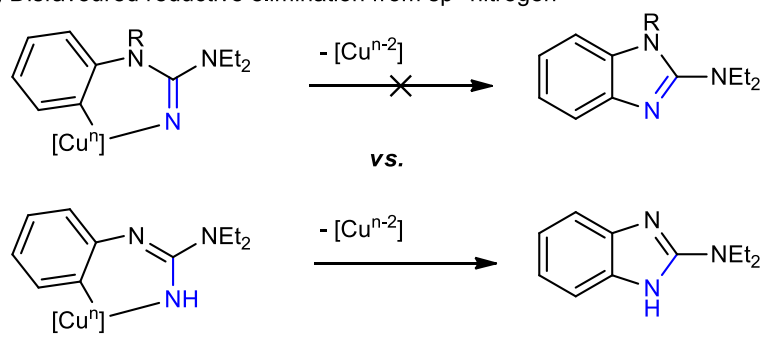

Finally, to exemplify the utility of this method we have developed a novel synthesis of Emedastine 2 with the benzimidazole formation performed on gram scale in good yield, isolating $1.7 \mathrm{~g}$ of the product 47 (Scheme 5). Treatment of prepared cyanamide $\mathbf{4 5}$ with aniline under basic conditions afforded $\mathbf{4 6}$, which, upon exposure to reoptimised reaction conditions gave benzimidazole $47(71 \%)$. We were able to lower the copper loading to $12.5 \%$ 
without a loss in yield, and the product was isolated through precipitation from tBME (see supporting information). Alkylation of $\mathbf{4 7}$ with alkyl iodide $\mathbf{4 8}$ allowed for preparation of the $\mathrm{N}$-alkylated benzimidazole $\mathbf{4 9}$ in an $\mathbf{8 9 \%}$ yield. Final deprotection/methylation furnished $\mathbf{2}$ in an $80 \%$ yield for the two steps. This route offers a $34 \%$ yield over 5 steps to an important pharmaceutical compound with aniline as the key starting material.

Scheme 5. Application of methodology to the synthesis of Emedastine

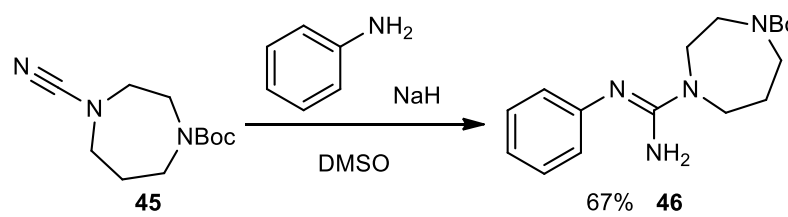<smiles>CCOCCn1c(N2CCCN(C(=O)OCC)CC2)nc2ccccc21</smiles>

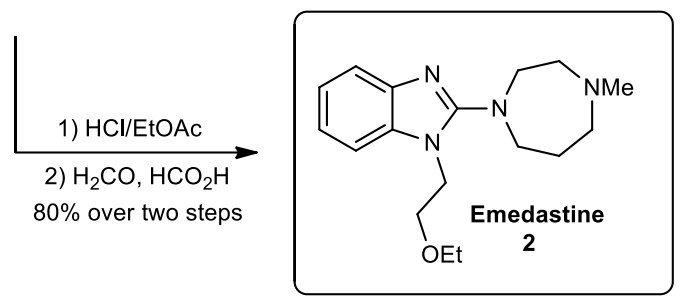

\section{Conclusions}

In summary, we have developed conditions for the direct formation of 2-aminobenzimidazoles from aryl guanidines under base-metal catalytic conditions using air as the terminal, green oxidant. Stabilisation of the catalytically active species is required using an electron donating 1,3-dicarbonyl ligand to avoid dimerisation of the benzimidazole product. The substrate scope of the reaction allows for a range of functional groups to be tolerated, and a selection of amine groups have been shown to be compatible with the reaction to afford substituted 2-aminobenzimidazoles that may have an application within medicinal chemistry. Finally, we have shown how products of significant pharmaceutical interest can be prepared using this method through the synthesis of Emedastine 2, a marketed second-generation antihistamine drug.

\section{Experimental}

All catalysts and reagents were supplied by commercial sources and used without further purification, unless otherwise stated. Sulfolane was purchased from AlfaAesar and was melted in a buchi-path heated to $50{ }^{\circ} \mathrm{C}$ before use. When degassed solvent was required, a sample was sealed in a microwave vial and frozen in a cardice/acetone bath at $-78{ }^{\circ} \mathrm{C}$, before being exposed to vacuum and warmed in a room temperature water bath. This process was repeated three times, or until bubbles no longer form on melting of the sample. Reactions were monitored using High Performance Liquid Chromatography (HPLC) and Liquid Chromatography-Mass Spectrometry (LCMS) (high pH), where the conditions are displayed in the SI. ${ }^{1} \mathrm{H},{ }^{13} \mathrm{C}$ and ${ }^{19} \mathrm{~F}$ NMR spectra were recorded using a Bruker AV-400. HPLC was conducted on a Waters X-select CSH C18 column (XP). High-resolution electrospray mass spectra were recorded on a Thermo Exactive orbitrap mass spectrometer equipped with a Waters Acquity UPLC system, solvent gradient is recorded in the SI. Automated column chromatography was performed on a Biotage SP4, Isolera 1 or Isolera 4 purification system monitored by UV $(\lambda=200-400 \mathrm{~nm}, \lambda=254 \mathrm{~nm}$ and $220 \mathrm{~nm})$ using, unless stated otherwise, Biotage ${ }^{\circledR}$ SNAP Ultra pre-packed cartridges or Biotage SNAP KP-NH cartridges. Reverse phase column 
chromatography was performed on a CombiFlash automated system using Biotage ${ }^{\circledR}$ SNAP KP-C ${ }_{18}$-HS pre-packed cartridge. Chromatographic solvents were standard HPLC grade provided by Honeywell, and when a modifier was required it was added in-house. Melting points were measured on an OptiMelt melting point apparatus and monitored manually. IR spectra were recorded using a Perkin Elmer Spectrum One spectrometer and the data processed using Perkim Elmer Spectrum software. Absorption frequencies (vmax) are reported in wavenumbers $\left(\mathrm{cm}^{-1}\right)$ of the peaks with the larger numbers away from the fingerprint region. The Mettler-Toledo Quantos QB5 or QX96 was used to weigh out desired solids for high throughput screening in pre-loaded dispensing heads using the supplied dispensing algorithms. Guanidine synthesis is described in the supporting information.

\section{Solvent screen.}

2-(3-methoxyphenyl)-1,1-dimethylguanidine (4) (95 mg, $0.5 \mathrm{mmol}$ ), copper(I) acetate ( $9 \mathrm{mg}, 0.074 \mathrm{mmol}, 0.15$ equiv) and pivalic acid (51 mg, $0.5 \mathrm{mmol}, 1$ equiv) were placed in a $4 \mathrm{~mL}$ vial which was equipped with a stir-bar. Solvent $(2 \mathrm{~mL})$ was added and the vial fitted with a hole-punched septum. The vial was placed in the Cat96 reactor and heated to $100^{\circ} \mathrm{C}$ under 6 bar of compressed air for $21 \mathrm{hr}$ before being analysed by HPLC analysis. Data is presented in a table in the supporting information.

\section{High throughput screen of copper sources, additives and solvents for the cyclisation of 4.}

To $0.5 \mathrm{~mL}$ glass vials were weighed the quoted masses (see $\mathrm{SI}$ ) of copper source and to the reactions containing basic additives added NaOAc/NaOPiv using the automated weighing platform Quantos QX96. To each vial was added 2-(3-methoxyphenyl)-1,1-dimethylguanidine (4) $(0.2 \mathrm{~mL}$ of a stock solution in the quoted solvent) such that each $0.2 \mathrm{~mL}$ delivers $25 \mathrm{mg} / 0.13 \mathrm{mmol}$ of substrate 4 . To the reactions containing acidic additives was added a further $0.2 \mathrm{~mL}$ of a stock solution of the desired acid in the quoted solvent such that the $0.2 \mathrm{~mL}$ delivers 1 equivalent of the desired acidic additive with respect to 4 . To the remaining reactions in which the basic additive was added as a solid, a further $0.2 \mathrm{~mL}$ of the quoted solvent was added to make the total reaction volume up to $0.4 \mathrm{~mL}(0.32 \mathrm{M}$ with respect to substrate 4). All reactions were then stirred with a magnetic flea and heated to $80{ }^{\circ} \mathrm{C}$ under 6 bar of compressed air in a CAT96 reactor for 16 hours before filtering and analysing by HPLC and LCMS. Displayed in the $\mathrm{SI}$ are the dispensed masses of solid reagents and the HPLC peak area \% data of starting material (4), product 5 and undesired dimeric product 6.

\section{Design of Experiments Optimisation procedure.}

To $4 \mathrm{~mL}$ glass tubes were added the masses of compounds highlighted table 1 in the $\mathrm{SI}$, where the respective loading of each is shown, relative to the amount of 7 . Each $4 \mathrm{~mL}$ glass tube was then fitted with a stir bar and sulfolane (1 $\mathrm{mL}$ ). To minimise mass-transfer effects of air, constant volume experiments were designed, hence the varying quantity of 7. $25 \mu \mathrm{L}$ samples were taken and diluted into acetonitrile $(500 \mu \mathrm{L})$, filtered and analysed by HPLC/LCMS at $1 \mathrm{~h}, 1.5 \mathrm{~h}, 4 \mathrm{~h}$ and $21 \mathrm{~h}$. Heating was performed with a heating mantle set to the quoted temperature. Raw HPLC data was then used to calculate HPLC area \% which is then shown in the main body of the text, displaying the 4 hour time-point data, from which we fitted the statistical model (full details of statistical model can be found in the SI)

\section{Reaction additive screening procedure.}

To an HPLC vial was added 1,1-dimethyl-2-(3-(trifluoromethyl)phenyl) guanidine (7) (50 mg, $0.22 \mathrm{mmol}$ ), 4,4'-ditertbutyl-1,1'-biphenyl (13 mg, $0.05 \mathrm{mmol} 0.23$ equiv), $\mathrm{Cu}(\mathrm{EAA}) 2$ (17 mg, $0.05 \mathrm{mmol}, 0.25$ equiv) and the desired carboxylic acid $\left(0.22 \mathrm{mmol}, 1\right.$ equiv) with sulfolane $(0.5 \mathrm{~mL})$. The reaction was stirred and heated to $100{ }^{\circ} \mathrm{C}$ with a heating mantle and analysed by HPLC using the response factor calculations to determine the solution yield of benzimidazole 8 after the quoted time. The table in the SI summarises the solution yield of 8 using the internal standard 4,4'-di-tertbutyl-1,1'-biphenyl.

\section{Synthesis of Guanidine Starting Materials (General Procedure 1).}


To a dry round-bottom flask was added a $60 \%$ suspension of sodium hydride (1.2 equiv) which was slurried in anhydrous DMSO $(0.5 \mathrm{~mL} / \mathrm{mmol}$ of $\mathrm{NaH})$. The flask was exposed to vacuum and back-filled with nitrogen for 3 cycles before cooling the flask to $0{ }^{\circ} \mathrm{C}$ and adding the aniline derivative (1.0 equiv) dropwise as a solution in anhydrous DMSO $\left(0.33 \mathrm{~mL} / \mathrm{mmol}\right.$ of aniline). The reaction was stirred at $0{ }^{\circ} \mathrm{C}$ for 15 minutes before addition of the cyanamide (1.2 equiv), at which point the reaction was allowed to warm to room temperature. After the stated time, the reaction was carefully quenched with water $(\sim 3 \mathrm{~mL} / \mathrm{mmol}$ of sodium hydride used) and extracted into tBME ( 3 washes of equal volume of the water solution). The combined organic extracts were washed with water ( 3 washes of $0.33 \times$ total organic volume), brine ( 1 wash of $0.33 \times$ total organic volume), dried over anhydrous MgSO 4 and concentrated in vacuo. The crude product was either purified by crystallisation or chromatography to yield the desired guanidine product. See the supporting information for full experimental and analytical data of guanidines.

\section{Cyclisation experiments}

\section{5-Methoxy-N,N-dimethyl-1H-benzo[d]imidazol-2-amine (5).}

To a dry Schlenk tube was added 2-(3-methoxyphenyl)-1,1-dimethylguanidine (4) (97 mg, $0.5 \mathrm{mmol}, 1$ equiv), pivalic acid (50 mg, $0.5 \mathrm{mmol}, 1.0$ equiv), copper(I) acetate (60 mg, $48.9 \mathrm{mmol}, 1.0$ equiv) and a stir bar. The Schlenk tube was fitted with a septum and the vessel exposed to vacuum before being back-filled with nitrogen. This process was repeated 3 times, and the reaction remained exposed to nitrogen. To the Schlenk tube was added freeze-pump thawed degassed NMP $(2 \mathrm{~mL})$. The sealed Schlenk tube was then placed in a silicone oil bath which had been preheated to $80^{\circ} \mathrm{C}$. After $21 \mathrm{~h}$, the reaction was removed from the oil bath and the septum taken out, allowing the solution to cool to room temperature. Water $(10 \mathrm{~mL})$ was added, causing a precipitate to form. On addition of tBME $(10 \mathrm{~mL})$ and $\mathrm{EDTA}_{\text {(aq) }}$ solution $(6 \mathrm{~mL}, 0.1 \mathrm{M}, 0.6 \mathrm{mmol}, 1.2$ equiv w.r.t copper(I) acetate), the aqueous layer turns green and the precipitate dissolves in the organic layer, which turns brown. The aqueous layer was extracted a further two times with tBME $(2 \times 15 \mathrm{~mL})$ and the combined organic extracts washed with water $(2 \times 15 \mathrm{~mL})$ and brine $(1 \times$ $10 \mathrm{~mL})$. The combined water and brine washes were back-extracted with tBME $(2 \times 10 \mathrm{~mL})$, and the five combined tBME extracts were concentrated in vacuo. The crude reaction mixture was purified by column chromatography (10 g Biotage ${ }^{\circledR}$ SNAP Ultra) $0-10 \% \mathrm{MeOH} / \mathrm{CH}_{2} \mathrm{Cl}_{2}$ to yield 5-methoxy- $\mathrm{N}, \mathrm{N}$-dimethyl-1 $\mathrm{H}$-benzo[d]imidazol-2-amine (5) as a white solid. (62 $\mathrm{mg}, 0.3 \mathrm{mmol}, 64 \%)$

${ }^{1} \mathrm{H}$ NMR $\left(400 \mathrm{MHz}\right.$, METHANOL- $\left.d_{4}\right) \delta$ ppm $3.09(6 \mathrm{H}, \mathrm{s}), 3.77(3 \mathrm{H}, \mathrm{s}), 6.60(1 \mathrm{H}, \mathrm{dd}, J=8.6,2.4 \mathrm{~Hz}), 6.82(1 \mathrm{H}, \mathrm{d}, J=$ $2.4 \mathrm{~Hz}), 7.08(1 \mathrm{H}, \mathrm{d}, J=8.6 \mathrm{~Hz}){ }^{13} \mathrm{C}\left\{{ }^{1} \mathrm{H}\right\}$ NMR (METHANOL-d $\left.4,101 \mathrm{MHz}\right) \delta \mathrm{ppm} 38.5,56.5,98.0,108.5,111.5,118.0$, $155.5,156.0,158.5$. The spectroscopic data is in agreement with those previously reported ${ }^{27}$

\section{5,6'-dimethoxy- $N^{2}, N^{2}, N^{2}, N^{2}$-tetramethyl-3'H-[1,5'-bibenzo[d]imidazole]-2,2'-diamine (6).}

To a vial containing 2-(3-Methoxyphenyl)-1,1-dimethylguanidine (4) (1.00 g, $5.17 \mathrm{mmol}, 1$ equiv), copper(I) acetate (634 mg, $5.17 \mathrm{mmol}, 1.0$ equiv) \& pivalic acid $(529 \mathrm{mg}, 5.17 \mathrm{mmol})$ was added NMP (17 mL). The reaction was heated to $80^{\circ} \mathrm{C}$ in the CAT96 pressure reactor under 6 bar compressed air for 16 hours. On cooling to room temperature, the solution was flushed through an SCX-2 ion exchange cartridge with $\mathrm{MeOH}(100 \mathrm{~mL})$, followed by a $7 \mathrm{~N}$ methanolic ammonia $(50 \mathrm{~mL})$. The methanolic ammonia solution was concentrated in vacuo and purified by chromatography $\left(0-10 \% \mathrm{MeOH} / \mathrm{CH}_{2} \mathrm{Cl}_{2}\right.$ with $2 \%$ triethylamine modifier in the $\left.\mathrm{CH}_{2} \mathrm{Cl}_{2}\right)$ to yield $126 \mathrm{mg}$ of a brown solid. The brown solid was then re-purified by reverse phase chromatography $\left(15-55 \% \mathrm{MeCN} / \mathrm{H}_{2} \mathrm{O}, \mathrm{NH}_{4} \mathrm{HCO}_{3}\right.$ modifier at $0.1 \%)$, the volatiles removed under reduced pressure, the aqueous extracted with $\mathrm{CH}_{2} \mathrm{Cl}_{2}(3 \times 30 \mathrm{~mL})$, before drying over a hydrophobic frit and concentrating in vacuo to yield 5,6'-dimethoxy- $\mathrm{N}^{2}, \mathrm{~N}^{2}, \mathrm{~N}^{2}, \mathrm{~N}^{2}$-tetramethyl-3' $H-\left[1,5^{\prime}-\right.$ bibenzo[d]imidazole]-2,2'-diamine 6 as a white solid (63 mg, $0.17 \mathrm{mmol}, 3 \%$ ).

${ }^{1} \mathrm{H}$ NMR $(400 \mathrm{MHz}$, METHANOL-d $) \delta$ ppm $2.84(6 \mathrm{H}, \mathrm{s}), 3.15(6 \mathrm{H}, \mathrm{s}), 3.76(3 \mathrm{H}, \mathrm{s}), 3.79(3 \mathrm{H}, \mathrm{s}), 6.53-6.60(2 \mathrm{H}$, $\mathrm{m}), 6.97(1 \mathrm{H}, \mathrm{d}, J=1.2 \mathrm{~Hz}), 7.09(1 \mathrm{H}, \mathrm{s}), 7.14(1 \mathrm{H}, \mathrm{s}){ }^{13} \mathrm{C}\left\{{ }^{1} \mathrm{H}\right\}$ NMR $(101 \mathrm{MHz}$, METHANOL-d $) \delta \mathrm{ppm} 37.2,39.3$, 54.9, 55.4, 96.5, 99.7, 107.5, 108.8, 118.3, 131.8, 141.6, 150.8, 156.0, 158.0, 158.4. Multiple signals missing from 13C NMR. Refer to supporting information for full spectroscopic data (2D NMRs) and structural elucidation. HRMS (ESI Orbitrap) $\mathrm{m} / \mathrm{z}$ : $[\mathrm{M}+\mathrm{H}]^{+}$Calcd for $\mathrm{C}_{20} \mathrm{H}_{24} \mathrm{~N}_{6} \mathrm{O}_{2}[\mathrm{M}+\mathrm{H}]^{+} 380.1960$, found $[\mathrm{M}+\mathrm{H}]^{+} 380.1963$ 


\section{General procedure 2 for aerobic copper catalysed dehydrogenative cyclisation to form benzimidazoles.}

Aryl guanidine, pivalic acid ( 1 equiv.) and copper(II) ethylacetoacetate ( 0.25 equiv.) were placed in a round bottom flask fitted with a magnetic stirring flea. Sulfolane was warmed using a heated water bath and the desired volume was dispensed by syringe to make up to a reaction concentration of $0.4 \mathrm{M}$. The reaction was stirred and heated to $100^{\circ} \mathrm{C}$ by heating mantle with the round bottom flask open to air. Reactions were monitored by HPLC analysis (CSH method) and the reactions were cooled to room temperature after the stated time. The reaction mixture was loaded directly onto an SCX-2 ion-exchange cartridge and homogenised with $\mathrm{MeOH}$, after which the cartridge was flushed with a further 15 column volumes of methanol. The cartridge was then flushed with 2 column volumes of a $2 \mathrm{M}$ methanolic ammonia solution to elute the product, which was then concentrated in vacuo and purified by flash column chromatography $\left(0-4 \% \mathrm{MeOH}\right.$ in $\mathrm{CH}_{2} \mathrm{Cl}_{2}$ in most cases unless stated otherwise) to yield the product.

\section{5-Trifluoromethyl-N,N-dimethyl-1Hbenzo[d]imidazol-2-amine (8).}

1-Dimethyl-2-(3-(trifluoromethyl)phenyl) guanidine (7) (370 mg, $1.6 \mathrm{mmol}, 1$ equiv), pivalic acid (163 mg, $1.6 \mathrm{mmol}$, 1.0 equiv) and copper(II) 2-ethylacetoacetate $(129 \mathrm{mg}, 0.4 \mathrm{mmol}, 0.25$ equiv) were placed in a round bottomed flask that was fitted with a stir bar. Sulfolane $(4 \mathrm{~mL})$ was added, and the reaction heated to $100{ }^{\circ} \mathrm{C}$. After $24 \mathrm{~h}$, the reaction was removed from the hotplate and allowed to cool to room temperature, at which point water $(20 \mathrm{~mL})$, EDTA (aq) $(5$ $\mathrm{mL}, 0.1 \mathrm{M}, 0.5 \mathrm{mmol}, 1.2$ equiv w.r.t copper.) and tBME (20 mL) was added. The organic layer was separated, and the aqueous layer extracted a further 2 times $(2 \times 15 \mathrm{~mL}$ tBME$)$, before the combined organic extracts were washed with water $(3 \times 10 \mathrm{~mL})$ and brine $(1 \times 20 \mathrm{~mL})$. The water and brine washes were then back-extracted with tBME $(1 \times$ $15 \mathrm{~mL})$. The combined organic extracts were then concentrated in vacuo and purified by column chromatography $\left(0-10 \% \mathrm{MeOH} / \mathrm{CH}_{2} \mathrm{Cl}_{2}\right)$ to yield (8) as an orange solid (196 $\left.\mathrm{mg}, 0.9 \mathrm{mmol}, 54 \%\right)$.

Melting point: $210-211^{\circ} \mathrm{C}$ FTIR $v_{\max } / \mathrm{cm}^{-1} 3073$ (br), 2925 (br), 1639, 1611, 1320. ${ }^{1} \mathrm{H}$ NMR $(400 \mathrm{MHz}$, METHANOL$\left.d_{4}\right) \delta$ ppm $3.15(6 \mathrm{H}, \mathrm{s}), 7.24-7.33(2 \mathrm{H}, \mathrm{m}), 7.45(1 \mathrm{H}, \mathrm{s}){ }^{13} \mathrm{C}\left\{{ }^{1} \mathrm{H}\right\} \mathrm{NMR}(101 \mathrm{MHz}$, METHANOL-d 4$) \square \square$ ppm 37.1, 108.2 (br.), 111.2 (br.), 116.9 (q, J=3.8 Hz), 121.9 (q, J=31.3 Hz), 125.3 (t, J=270.1 Hz), 138.2 (br.), 141.1 (br.), 157.8 (br.) ${ }^{19} \mathrm{~F}$ NMR (376 MHz, METHANOL-d $) \delta$ ppm -61.8 (s) HRMS (ESI Orbitrap) m/z: [M + H] ${ }^{+}$Calcd for $\mathrm{C}_{10} \mathrm{H}_{11} \mathrm{~F}_{3} \mathrm{~N}_{3}$ $[\mathrm{M}+\mathrm{H}]^{+} 230.0900$, found $[\mathrm{M}+\mathrm{H}]^{+} 230.0893$

\section{4-fluoro-N,N-dimethyl-1H-benzo[d]imidazol-2-amine (9).}

Using general procedure 2 for benzimidazole formation was performed with 2-(2-fluorophenyl)-1,1-dimethylguanidine (51) (201 mg, $1.1 \mathrm{mmol}), \mathrm{Cu}(\mathrm{EAA})_{2}$ ( $89 \mathrm{mg}, 0.3 \mathrm{mmol}, 0.25$ equiv) and pivalic acid (114 mg, $1.1 \mathrm{mmol}, 1.0$ equiv) for 19 hours to yield 4-fluoro- $N, N$-dimethyl- $1 \mathrm{H}$-benzo[d]imidazol-2-amine (9) as an off-white solid. (92 mg, $0.5 \mathrm{mmol}$, $46 \%)$

Melting point: $232-234{ }^{\circ} \mathrm{C}$ FTIR $v_{\max } / \mathrm{cm}^{-1} 2921,1634,1578,1509,1415 .{ }^{1} \mathrm{H}$ NMR $(400 \mathrm{MHz}$, METHANOL-d $) \delta \mathrm{ppm}$ $3.16(6 \mathrm{H}, \mathrm{s}), 6.76(1 \mathrm{H}, \mathrm{ddd}, \mathrm{J}=10.9,8.2,0.6 \mathrm{~Hz}), 6.90-6.96(1 \mathrm{H}, \mathrm{m}), 7.01-7.06(1 \mathrm{H}, \mathrm{m}){ }^{13} \mathrm{C}\left\{{ }^{1} \mathrm{H}\right\} \mathrm{NMR}(101 \mathrm{MHz}$, METHANOL-d $\left.d_{4}\right) \delta$ ppm 38.7, 107.6 (d, J=17.7 Hz), 107.9 (br), $121.2(\mathrm{~d}, \mathrm{~J}=7.1 \mathrm{~Hz}), 129.1$ (br), 141.0 (br), 151.6 (d, J=243.2 Hz), 158.5 (br) $\left.{ }^{19} \mathrm{~F} \mathrm{NMR} \mathrm{(376} \mathrm{MHz,} \mathrm{METHANOL-d}\right) \square \square$ ppm -135.4 HRMS (ESI Orbitrap) m/z: [M + H] Calcd for $\mathrm{C}_{9} \mathrm{H}_{11} \mathrm{FN}_{3}[\mathrm{M}+\mathrm{H}]^{+}$180.0937, found $[\mathrm{M}+\mathrm{H}]^{+} 180.0938$.

\section{N,N-dimethyl-1H-benzo[d]imidazol-2-amine(10).}

Using general procedure 2 for benzimidazole formation was performed with 1,1-dimethyl-2-phenylguanidine (27) (201 mg, $1.2 \mathrm{mmol}$ ), $\mathrm{Cu}(\mathrm{EAA})_{2}$ (98 mg, $0.3 \mathrm{mmol}, 0.25$ equiv) and pivalic acid (125 mg, $1.2 \mathrm{mmol}, 1.0$ equiv) for 24 hours to yield $N, N$-dimethyl-1 $H$-benzo[d]imidazol-2-amine (10) as an off-white solid. (129 mg, $0.8 \mathrm{mmol}, 65 \%$ )

Melting point: 202-204 ${ }^{\circ} \mathrm{C}$ FTIR $v_{\max } / \mathrm{cm}^{-1}$ 2918, 1634, 1603, 1575 (br), 1425, 1411. ${ }^{1} \mathrm{H}$ NMR $(400 \mathrm{MHz}$, METHANOLd4) $\delta$ ppm 3.08 - $3.25(6 \mathrm{H}, \mathrm{s}), 6.99(2 \mathrm{H}, \mathrm{dd}, \mathrm{J}=5.8,3.3 \mathrm{~Hz}), 7.24(2 \mathrm{H}, \mathrm{dd}, \mathrm{J}=5.8,3.3 \mathrm{~Hz}){ }^{13} \mathrm{C}\left\{{ }^{1} \mathrm{H}\right\} \mathrm{NMR}(101 \mathrm{MHz}$, 
METHANOL- $\left.d_{4}\right) \delta$ ppm 37.2, $111.2(b r), 119.8,138.1(b r), 156.6$ HRMS (ESI Orbitrap) m/z: [M + H] $]^{+}$Calcd for $\mathrm{C}_{9} \mathrm{H}_{12} \mathrm{~N}_{3}[\mathrm{M}+\mathrm{H}]^{+}$162.1031, found $[\mathrm{M}+\mathrm{H}]^{+}$162.1033. The spectroscopic data is in agreement with those previously reported. ${ }^{22}$

\section{Ethyl 2-(dimethylamino)-1H-benzo[d]imidazole-6-carboxylate (11).}

Using general procedure 2 for benzimidazole formation was performed with ethyl 4((amino(dimethylamino)methylene)amino)benzoate (52) $(50 \mathrm{mg}, 0.2 \mathrm{mmol}), \mathrm{Cu}(\mathrm{EAA}) 2$ (18 mg, $0.06 \mathrm{mmol}, 0.27$ equiv) and pivalic acid (22 mg, $0.2 \mathrm{mmol}, 1.0$ equiv) for 14.5 hours to yield ethyl 2-(dimethylamino)-1Hbenzo[d]imidazole-6-carboxylate (11) as an off-white solid. (31 $\mathrm{mg}, 0.13 \mathrm{mmol}, 63 \%$ )

Melting point: $210-212{ }^{\circ} \mathrm{C} \mathrm{FTIR} \mathrm{v}_{\max } / \mathrm{cm}^{-1} 3193,2981,1693,1638,1602,1297 .{ }^{1} \mathrm{H}$ NMR $\left(400 \mathrm{MHz}, \mathrm{METHANOL-} \mathrm{d}_{4}\right)$ $\delta$ ppm $1.27(3 \mathrm{H}, \mathrm{t}, \mathrm{J}=7.1 \mathrm{~Hz}), 3.02(6 \mathrm{H}, \mathrm{s}), 4.22(2 \mathrm{H}, \mathrm{q}, \mathrm{J}=7.1 \mathrm{~Hz}), 7.12(1 \mathrm{H}, \mathrm{d}, \mathrm{J}=8.2 \mathrm{~Hz}), 7.62(1 \mathrm{H}, \mathrm{dd}, \mathrm{J}=8.2$, $1.5 \mathrm{~Hz}), 7.75(1 \mathrm{H}, \mathrm{d}, J=1.5 \mathrm{~Hz}){ }^{13} \mathrm{C}\left\{{ }^{1} \mathrm{H}\right\}$ NMR $(101 \mathrm{MHz}$, METHANOL-d $) \quad \delta \mathrm{ppm}$ 14.8, 38.5, 61.7, 112.7 (br), 113.7 , 123.0, 123.9, 138.5, 145.2, 159.6, 169.2 HRMS (ESI Orbitrap) $\mathrm{m} / \mathrm{z}$ : $[\mathrm{M}+\mathrm{H}]^{+}$Calcd for $\mathrm{C}_{12} \mathrm{H}_{16} \mathrm{~N}_{3} \mathrm{O}_{2}[\mathrm{M}+\mathrm{H}]^{+}$234.1237, found $[\mathrm{M}+\mathrm{H}]^{+} 234.1227$.

\section{2-(Dimethylamino)-1H-benzo[d]imidazole-6-carbo- nitrile (13).}

Using general procedure 2 for benzimidazole formation was performed with 2-(4-cyanophenyl)-1,1dimethylguanidine (53) (292 mg, $1.6 \mathrm{mmol}), \mathrm{Cu}(\mathrm{EAA})_{2}(115 \mathrm{mg}, 0.4 \mathrm{mmol}, 0.25$ equiv) and pivalic acid (158 mg, 1.6 mmol, 1.0 equiv) for 24 hours to yield 2-(dimethylamino)-1 $H$-benzo[d] imidazole-6-carbonitrile (13) as a brown solid (114 mg, $0.61 \mathrm{mmol}, 40 \%)$

${ }^{1} \mathrm{H}$ NMR $(400 \mathrm{MHz}$, METHANOL-d $) \delta$ ppm $3.18(6 \mathrm{H}, \mathrm{s}), 7.28-7.38(2 \mathrm{H}, \mathrm{m}), 7.49(1 \mathrm{H}, \mathrm{s}){ }^{13} \mathrm{C}\left\{{ }^{1} \mathrm{H}\right\} \mathrm{NMR}(101 \mathrm{MHz}$, METHANOL-d $d_{4} \delta$ ppm 38.7, 103.0, 113.8, 121.9, 126.0, 139.1 (br), 140.2 (br), 159.9 HRMS (ESI Orbitrap) m/z: [M $+\mathrm{H}]^{+}$Calcd for $\mathrm{C}_{10} \mathrm{H}_{11} \mathrm{~N}_{4}[\mathrm{M}+\mathrm{H}]^{+}$187.0978, found [M + H]+ 187.0972. FTIR: 2978, 2210 (CN), 1639, 1599, 1574, $1470 \mathrm{~cm}^{-1}$. The spectroscopic data is in agreement with those previously reported. ${ }^{28}$

\section{Tert-butyl 2-(dimethylamino)-1H-benzo[d]- imidazole-5-carboxylate (12).}

Using general procedure 2 for benzimidazole formation was performed with tert-butyl 4-((amino(dimethylamino)methylene)amino)benzoate (54) $(259 \mathrm{mg}, 1.0 \mathrm{mmol}), \mathrm{Cu}(\mathrm{EAA})_{2}(81 \mathrm{mg}, 0.25 \mathrm{mmol}, 0.26$ equiv) and pivalic acid (102 mg, $1.0 \mathrm{mmol}, 1.0$ equiv) for 25 hours to yield tert-butyl 2-(dimethylamino)-1 $\mathrm{H}$-benzo[d]imidazole-5carboxylate (12) as a brown solid. (137 $\mathrm{mg}, 0.52 \mathrm{mmol}, 53 \%)$

Melting point: $216-218{ }^{\circ} \mathrm{C}$ FTIR $v_{\max } / \mathrm{cm}^{-1} 2981,1695,1635,1605,1574 .{ }^{1} \mathrm{H}$ NMR $\left(400 \mathrm{MHz}, \mathrm{METHANOL-d_{4 } )} \square \square\right.$ ppm $1.61(9 \mathrm{H}, \mathrm{s}), 3.15(6 \mathrm{H}, \mathrm{s}), 7.23(1 \mathrm{H}, \mathrm{d}, \mathrm{J}=8.3 \mathrm{~Hz}), 7.69(1 \mathrm{H}, \mathrm{dd}, \mathrm{J}=8.3,1.1 \mathrm{~Hz}), 7.83\left(1 \mathrm{H}\right.$, app. s) ${ }^{13} \mathrm{C}\left\{{ }^{1} \mathrm{H}\right\} \mathrm{NMR}$ (101 MHz, METHANOL-d4) $\delta$ ppm 167.1, 123.2, 122.3, 112.0, 111.0, 80.1, 37.1, 27.2 Not all signals are present by NMR. $1 \times$ aliphatic carbon missing from spectra and $1 \times$ quaternary carbon. NMR sample was saturated $(\sim 100 \mathrm{mg}$ in solution) and number of scans set to 10,000. HRMS (ESI Orbitrap) $\mathrm{m} / \mathrm{z}:[\mathrm{M}+\mathrm{H}]^{+}$Calcd for $\mathrm{C}_{14} \mathrm{H}_{20} \mathrm{~N}_{3} \mathrm{O}_{2}[\mathrm{M}+\mathrm{H}]^{+}$ 262.1550, found $[\mathrm{M}+\mathrm{H}]^{+} 262.1539$.

\section{5-Bromo-N,N-dimethyl-1H-benzo[d]imidazol-2-amine (14).}

Using general procedure 2 for benzimidazole formation was performed with 2-(4-bromophenyl)-1,1dimethylguanidine (55) (174 mg, $0.72 \mathrm{mmol}), \mathrm{Cu}(\mathrm{EAA})_{2}(59 \mathrm{mg}, 0.18 \mathrm{mmol}, 0.25$ equiv) and pivalic acid $(74 \mathrm{mg}$, $0.72 \mathrm{mmol}, 1.0$ equiv) for 14.5 hours to yield 5 -bromo- $\mathrm{N}, \mathrm{N}$-dimethyl- $1 \mathrm{H}$-benzo[d]imidazol-2-amine (14) as an offwhite solid. (100 mg, $0.42 \mathrm{mmol}, 58 \%$ )

Melting point: $244-245^{\circ} \mathrm{C}$ FTIR $v_{\max } / \mathrm{cm}^{-1}$ 2981, 1630, 1602, 1568, 1459, 1408. ${ }^{~} \mathrm{H}$ NMR $(400 \mathrm{MHz}$, METHANOL-d $)$ $\delta$ ppm $3.13(6 \mathrm{H}, \mathrm{s}), 7.06-7.14(2 \mathrm{H}, \mathrm{m}), 7.34(1 \mathrm{H}, \mathrm{s}){ }^{13} \mathrm{C}\left\{{ }^{1} \mathrm{H}\right\}$ NMR $(101 \mathrm{MHz}$, METHANOL-d 4$)$ ppm 38.6, 113.6, 113.8, 116.0, 123.9, 138.1, 141.8, 158.7 HRMS (ESI Orbitrap) m/z: $[\mathrm{M}+\mathrm{H}]^{+}$Calcd for $\mathrm{C}_{9} \mathrm{H}_{11} \mathrm{~N}_{3}{ }^{79} \mathrm{Br}$ $[\mathrm{M}+\mathrm{H}]^{+} 240.0131$, found $[\mathrm{M}+\mathrm{H}]^{+} 240.0121$. The spectroscopic data is in agreement with those previously reported ${ }^{29}$ 


\section{5-Chloro-N,N-dimethyl-1H-benzo[d]imidazol-2-amine (15) and 4-Chloro-N,N-dimethyl-1H-benzo[d]imidazol-2- amine (16).}

Using general procedure 2 for benzimidazole formation was performed with 2-(3-chlorophenyl)-1,1dimethylguanidine (56) (203 mg, $1.02 \mathrm{mmol}), \mathrm{Cu}(E A A)_{2}(82 \mathrm{mg}, 0.25 \mathrm{mmol}, 0.25$ equiv) and pivalic acid (104 mg, $1.02 \mathrm{mmol}, 1.0$ equiv) for 22 hours. The reaction was worked-up as described general procedure 2 , and purified by chromatography using a SNAP KP-NH $28 \mathrm{~g}$ column $(60 \%$ EtOAc / Heptane $\rightarrow$ EtOAc) to isolate 5-chloro- $N, N-$ dimethyl-1 $\mathrm{H}$-benzo[d]imidazol-2-amine (15) as a white solid $(61 \mathrm{mg}, 0.31 \mathrm{mmol}, 30 \%)$. The fractions containing impure 4-chloro- $N, N$-dimethyl-1H-benzo[d] imidazol-2-amine (16) were re-purified by chromatography $(3 \%$ $\mathrm{MeOH} / \mathrm{CH}_{2} \mathrm{Cl}_{2}, 10 \mathrm{~g}$ SNAP Ultra cartridge) to yield 4-chloro- $N, N$-dimethyl-1 $\mathrm{H}$-benzo[d]imidazol-2-amine (16) as a white solid (10 mg, $0.05 \mathrm{mmol}, 5 \%$ )

4-Chloro- $N, N$-dimethyl-1 $H$-benzo[d]imidazol-2-amine (16)

${ }^{1} \mathrm{H}$ NMR $\left(400 \mathrm{MHz}\right.$, METHANOL- $\left.d_{4}\right) \delta$ ppm $3.15(6 \mathrm{H}, \mathrm{s}), 6.91(1 \mathrm{H}, \mathrm{d}, \mathrm{J}=8.0 \mathrm{~Hz}), 6.97(1 \mathrm{H}, \mathrm{dd}, \mathrm{J}=8.0,1.1 \mathrm{~Hz}), 7.12$ $(1 \mathrm{H}, \mathrm{dd}, J=8.0,1.1 \mathrm{~Hz}){ }^{13} \mathrm{C}\left\{{ }^{1} \mathrm{H}\right\}$ NMR $(101 \mathrm{MHz}$, METHANOL-d $) \delta$ ppm 39.1, $121.4-122.1$ (br), 159.0 Multiple signals missing from spectra. Broad signal at 121-122 ppm is at least two signals. It is likely that the quaternary carbons are the non-observable signals and the lack of material meant a more resolved spectrum was not obtained. HRMS Calculated for $\mathrm{C}_{9} \mathrm{H}_{11} \mathrm{~N}_{3} \mathrm{Cl}[\mathrm{M}+\mathrm{H}]^{+} 196.0636$, found [M + H]+ 196.0646.

5-Chloro- $\mathrm{N}, \mathrm{N}$-dimethyl-1 $\mathrm{H}$-benzo[d]imidazol-2-amine (15) ${ }^{1} \mathrm{H}$ NMR $\left(400 \mathrm{MHz}, \mathrm{METHANOL-d_{4 } )} \square \square \mathrm{ppm} 3.11(6 \mathrm{H}\right.$, s), $6.94(1 \mathrm{H}, \mathrm{dd}, J=8.4,1.9 \mathrm{~Hz}), 7.13(1 \mathrm{H}, \mathrm{d}, J=8.4 \mathrm{~Hz}), 7.17(1 \mathrm{H}, \mathrm{d}, \mathrm{J}=1.9 \mathrm{~Hz})$ HRMS (ESI Orbitrap) m/z: [M + H] Calcd for $\mathrm{C}_{9} \mathrm{H}_{11} \mathrm{~N}_{3} \mathrm{Cl}[\mathrm{M}+\mathrm{H}]^{+} 196.0636$, found $[\mathrm{M}+\mathrm{H}]^{+} 196.0645$. Melting point: $245-247^{\circ} \mathrm{C}$ The spectroscopic data is in agreement with those previously reported ${ }^{30}$

\section{5-Bromo- $\mathrm{N}, \mathrm{N}$-dimethyl-1 $\mathrm{H}$-benzo[d]imidazol-2-amine (17) and 4-Bromo- $\mathrm{N}, \mathrm{N}$-dimethyl-1 $\mathrm{H}$-benzo[d]imidazol-2- amine (18).}

Using general procedure 2 for benzimidazole formation was performed with 2-(3-bromophenyl)-1,1dimethylguanidine (57) (201 mg, $0.83 \mathrm{mmol}), \mathrm{Cu}(\mathrm{EAA})_{2}(67 \mathrm{mg}, 0.21 \mathrm{mmol}, 0.25$ equiv) and pivalic acid (86 mg, $0.84 \mathrm{mmol}, 1.0$ equiv) for 18 hours. 5-bromo- $N, N$-dimethyl-1 $\mathrm{H}$-benzo[d]imidazol-2-amine (17) was isolated as a brown solid (130 mg, $0.54 \mathrm{mmol}, 66 \%$ ). The fractions containing impure 4-bromo- $\mathrm{N}, \mathrm{N}$-dimethyl- $\mathrm{H}$-benzo[d]imidazol2-amine (18) were re-purified by chromatography $\left(3 \% \mathrm{MeOH} / \mathrm{CH}_{2} \mathrm{Cl}_{2}, 10 \mathrm{~g}\right.$ SNAP Ultra cartridge) to yield 4-bromo$\mathrm{N}, \mathrm{N}$-dimethyl- $1 \mathrm{H}$-benzo[d]imidazol-2-amine (18) as a brown foam (49 mg, $0.21 \mathrm{mmol}, 25 \%) .5$-Bromo- $N, N$-dimethyl$1 H$-benzo[d]imidazol-2-amine (17)

Melting point: $244-246{ }^{\circ} \mathrm{C}$ FTIR $v_{\max } / \mathrm{cm}^{-1} 2921,2859,1628,1603,1578,1459,1409,1278 .{ }^{1} \mathrm{H}$ NMR $(400 \mathrm{MHz}$, METHANOL-d $\left.d_{4}\right) \delta$ ppm $3.12(6 \mathrm{H}, \mathrm{s}), 7.05-7.12(2 \mathrm{H}, \mathrm{m}), 7.32(1 \mathrm{H}, \mathrm{d}, \mathrm{J}=1.1 \mathrm{~Hz}){ }^{13} \mathrm{C}\left\{{ }^{1} \mathrm{H}\right\} \mathrm{NMR}(101 \mathrm{MHz}$, METHANOL-d $\left.d_{4}\right) \delta$ ppm 38.6, 113.6, 113.8, 116.0, 123.9, 138.1, 141.8, 158.7 HRMS (ESI Orbitrap) m/z: [M + H] $]^{+}$ Calcd for $\mathrm{C}_{9} \mathrm{H}_{11} \mathrm{~N}_{3} \mathrm{Br}[\mathrm{M}+\mathrm{H}]+240.0131$, found $[\mathrm{M}+\mathrm{H}]+2$ 240.0143. The spectroscopic data is in agreement with those previously reported ${ }^{29}$

4-Bromo-N,N-dimethyl-1H-benzo[d]imidazol-2-amine (18) ${ }^{11} \mathrm{H}$ NMR $\left(400 \mathrm{MHz}, M E T H A N O L-d_{4}\right) \delta \mathrm{ppm} 3.18(6 \mathrm{H}, \mathrm{s})$, $6.89(1 \mathrm{H}, \mathrm{d}, J=7.9 \mathrm{~Hz}), 7.15(1 \mathrm{H}, \mathrm{dd}, J=7.9,0.8 \mathrm{~Hz}), 7.18\left(1 \mathrm{H}, \mathrm{dd}, J=7.9,0.8 \mathrm{~Hz}{ }^{13} \mathrm{C}\left\{{ }^{1} \mathrm{H}\right\} \mathrm{NMR}(101 \mathrm{MHz}\right.$, $\left.M E T H A N O L-d_{4}\right) \delta \mathrm{ppm}$. Low sample quantity and rapid tautomerisation meant multiple peaks were missing from the 13C NMR. HRMS (ESI Orbitrap) m/z: [M + H]+ Calcd for $\mathrm{C}_{9} \mathrm{H}_{11} \mathrm{~N}_{3} \mathrm{Br}[\mathrm{M}+\mathrm{H}]^{+} 240.0131$, found $[\mathrm{M}+\mathrm{H}]^{+} 240.0144$. 
Using general procedure 2 for benzimidazole formation was modified to $90{ }^{\circ} \mathrm{C}$ but otherwise identical with 2(benzo[d][1,3]dioxol-5-yl)-1,1-dimethylguanidine (58) (50 mg, $0.24 \mathrm{mmol}), \mathrm{Cu}(\mathrm{EAA})_{2}(19 \mathrm{mg}, 0.06 \mathrm{mmol}, 0.25$ equiv) and pivalic acid ( $25 \mathrm{mg}, 0.24 \mathrm{mmol}, 1.0$ equiv) for 12 hours. The products were purified by chromatography using the standard method to yield $\mathrm{N}, \mathrm{N}$-dimethyl-5H-[1,3]dioxolo[4',5':4,5]benzo[1,2-d]imidazol-6-amine (19) as an off-white solid (14 mg, $0.07 \mathrm{mmol}, 28 \%)$ and $N, N$-dimethyl-8H-[1,3]dioxolo[4',5':3,4] benzo[1,2-d]imidazol-7-amine (20) as an off white solid (26 mg, $0.13 \mathrm{mmol}, 53 \%$ )

$\mathrm{N}, \mathrm{N}$-dimethyl-8H-[1,3]dioxolo[4',5':3,4]benzo[1,2-d]imidazol-7-amine (20) Melting point: $110-112{ }^{\circ} \mathrm{C} \mathrm{FTIR} \mathrm{V}_{\max } / \mathrm{cm}^{-1}$ 3357, 3126 (br), 1664, 1622, 1603, 1463. ${ }^{1} \mathrm{H}$ NMR (400 MHz, METHANOL-d $) \delta$ ppm $2.99(6 \mathrm{H}, \mathrm{s}), 5.80(2 \mathrm{H}, \mathrm{s})$, $6.43(1 \mathrm{H}, \mathrm{d}, \mathrm{J}=8.2 \mathrm{~Hz}), 6.55(1 \mathrm{H}, \mathrm{d}, J=8.2 \mathrm{~Hz}){ }^{13} \mathrm{C}\left\{{ }^{1} \mathrm{H}\right\}$ NMR an informative $13 \mathrm{C}$ spectra could not be obtained due to the low sample quantity and multiple peaks were not present in the spectra. All of the available material was loaded into the NMR tube, despite this, the signals were not detectable above the baseline, even when increasing the number of scans to 8192. HRMS (ESI Orbitrap) $\mathrm{m} / \mathrm{z}$ : $[\mathrm{M}+\mathrm{H}]^{+}$Calcd for $\mathrm{C}_{10} \mathrm{H}_{12} \mathrm{~N}_{3} \mathrm{O}_{2}[\mathrm{M}+\mathrm{H}]^{+}$206.0924, found [M + H] 206.0916. N,N-dimethyl-5H-[1,3]dioxolo[4',5':4,5]benzo[1,2-d]imidazol-6-amine (19) Melting point: > $400{ }^{\circ} \mathrm{C}$ FTIR $V_{\max } / \mathrm{cm}^{-1}$ 2981, 2867, 1623, 1601, 1496, 1463, 1423. ${ }^{1} \mathrm{H}$ NMR $(400 \mathrm{MHz}$, METHANOL-d $) \delta$ ppm $2.96(6 \mathrm{H}, \mathrm{s}), 5.73$ $(2 \mathrm{H}, \mathrm{s}), 6.64(2 \mathrm{H}, \mathrm{s}){ }^{13} \mathrm{C}\left\{{ }^{1} \mathrm{H}\right\}$ an informative ${ }^{13} \mathrm{C}$ spectra could not be obtained due to the low sample quantity and multiple peaks were not present in the spectra. Sample saturation was performed (as above) in an attempt to afford a more informative spectrum. HRMS (ESI Orbitrap) $\mathrm{m} / \mathrm{z}$ : [M + H]+ Calcd for $\mathrm{C}_{10} \mathrm{H}_{12} \mathrm{~N}_{3} \mathrm{O}_{2}[\mathrm{M}+\mathrm{H}]^{+} 206.0924$, found [M $+\mathrm{H}]^{+} 206.0915$.

\section{N,N-diethyl-1H-benzo[d]imidazol-2-amine (21).}

Using general procedure 2 for benzimidazole formation was performed with 1,1-diethyl-2-phenylguanidine (59) (256 $\mathrm{mg}, 1.34 \mathrm{mmol}$ ), $\mathrm{Cu}(\mathrm{EAA})_{2}$ (108 mg, $0.34 \mathrm{mmol}, 0.25$ equiv) and pivalic acid (139 mg, $1.36 \mathrm{mmol}, 1.0$ equiv) for 19 hours to yield $\mathrm{N}, \mathrm{N}$-diethyl-1 $\mathrm{H}$-benzo[d]imidazol-2-amine (21) as a pale orange solid. (118 $\mathrm{mg}, 0.62 \mathrm{mmol}, 46 \%$ )

Melting point: $202-204^{\circ} \mathrm{C}$ FTIR $v_{\max } / \mathrm{cm}^{-1} 2964,2871,1625,1599,1567 .{ }^{1} \mathrm{H}$ NMR $\left(400 \mathrm{MHz}, \mathrm{METHANOL-} d_{4}\right) \delta \mathrm{ppm}$ $1.24(6 \mathrm{H}, \mathrm{t}, J=7.0 \mathrm{~Hz}), 3.51(4 \mathrm{H}, \mathrm{q}, J=7.0 \mathrm{~Hz}), 6.97(2 \mathrm{H}, \mathrm{dd}, J=5.5,3.2 \mathrm{~Hz}), 7.22(2 \mathrm{H}, \mathrm{dd}, J=5.5,3.2 \mathrm{~Hz}){ }^{13} \mathrm{C}\left\{{ }^{1} \mathrm{H}\right\}$ NMR (101 MHz, METHANOL-d 4 ) $\delta$ ppm 12.3, 42.6, 111.2, 119.7, 138.2 (br), 155.1 HRMS (ESI Orbitrap) m/z: [M + $\mathrm{H}]^{+}$Calcd for $\mathrm{C}_{11} \mathrm{H}_{16} \mathrm{~N}_{3}[\mathrm{M}+\mathrm{H}]^{+}$190.1339, found $[\mathrm{M}+\mathrm{H}]^{+} 190.1331$.

\section{2-(Piperidin-1-yl)-1H-benzo[d]imidazole (23).}

Using general procedure 2 for benzimidazole formation was performed with $N$-phenylpiperidine-1-carboximidamide (60) $(263 \mathrm{mg}, 1.29 \mathrm{mmol}), \mathrm{Cu}(\mathrm{EAA})_{2}(101 \mathrm{mg}, 0.32 \mathrm{mmol}, 0.25$ equiv) and pivalic acid (137 mg, $1.34 \mathrm{mmol}, 1.0$ equiv) for 24 hours to yield 2-(piperidin-1-yl)-1H-benzo[d]imidazole (23) as a pale orange solid. (108 mg, $0.54 \mathrm{mmol}$, $41 \%)$

Melting point: $276-278{ }^{\circ} \mathrm{C}$ FTIR $v_{\max } / \mathrm{cm}^{-1} 2947,2849,1625,1565,1542 .{ }^{1} \mathrm{H}$ NMR $\left(400 \mathrm{MHz}, \mathrm{METHANOL-} d_{4}\right) \delta \mathrm{ppm}$ $1.65-1.77(6 \mathrm{H}, \mathrm{m}), 3.47-3.58(4 \mathrm{H}, \mathrm{m}), 6.99(2 \mathrm{H}, \mathrm{dd}, \mathrm{J}=5.6,3.1 \mathrm{~Hz}), 7.23(2 \mathrm{H}, \mathrm{dd}, \mathrm{J}=5.6,3.1 \mathrm{~Hz}){ }^{13} \mathrm{C}\left\{{ }^{1} \mathrm{H}\right\} \mathrm{NMR}$ (101 MHz, METHANOL-d4) $\delta$ ppm 23.9, 25.0, 47.0, 111.7 (br.), 120.0, 156.5 One 13C signal is missing. HRMS (ESI Orbitrap) $\mathrm{m} / \mathrm{z}$ : $[\mathrm{M}+\mathrm{H}]^{+}$Calcd for $\mathrm{C}_{12} \mathrm{H}_{16} \mathrm{~N}_{3}[\mathrm{M}+\mathrm{H}]^{+}$202.1339, found $[\mathrm{M}+\mathrm{H}]^{+} 202.1329$. The spectroscopic data is in agreement with those previously reported ${ }^{31}$

\section{4-(1H-Benzo[d]imidazol-2-yl)morpholine (24).}

Using general procedure 2 for benzimidazole formation was performed with $N$-phenylmorpholine-1-carboximidamide (61) $(250 \mathrm{mg}, 1.22 \mathrm{mmol}), \mathrm{Cu}(\mathrm{EAA})_{2}(98 \mathrm{mg}, 0.31 \mathrm{mmol}, 0.25$ equiv) and pivalic acid (126 mg, $1.23 \mathrm{mmol}, 1.0$ equiv) for 24 hours to yield 4-(1H-benzo[d]imidazol-2-yl)morpholine (24) as an off-white solid. (129 mg, $0.64 \mathrm{mmol}, 52 \%$ ) Melting point: $286-287^{\circ} \mathrm{C}$ FTIR $v_{\max } / \mathrm{cm}^{-1} 2981,2848,1625,1560,1451 .{ }^{1} \mathrm{H}$ NMR $\left(400 \mathrm{MHz}, \mathrm{METHANOL-d_{4 } )} \delta \mathrm{ppm}\right.$ $3.44-3.54(4 \mathrm{H}, \mathrm{m}), 3.76-3.85(4 \mathrm{H}, \mathrm{m}), 7.03(2 \mathrm{H}, \mathrm{dd}, J=5.3,3.2 \mathrm{~Hz}), 7.28(2 \mathrm{H}, \mathrm{dd}, J=5.3,3.2 \mathrm{~Hz}){ }^{13} \mathrm{C}\left\{{ }^{1} \mathrm{H}\right\} \mathrm{NMR}$ (101 MHz, METHANOL-d $) \delta$ ppm 46.3, 65.9, 112.0, 120.4, 137.6 (br), 156.3 (br) HRMS (ESI Orbitrap) m/z: [M + 
$\mathrm{H}]^{+}$Calcd for $\mathrm{C}_{11} \mathrm{H}_{14} \mathrm{~N}_{3} \mathrm{O}[\mathrm{M}+\mathrm{H}]^{+}$204.1131, found $[\mathrm{M}+\mathrm{H}]^{+}$204.1121. The spectroscopic data is in agreement with those previously reported 22

\section{6-Bromo-N,N-diethyl-1H-benzo[d]imidazol-2-amine (22).}

Using general procedure 2 for benzimidazole formation was performed with 2-(4-bromophenyl)-1,1-diethylguanidine (62) $(217 \mathrm{mg}, 0.80 \mathrm{mmol}), \mathrm{Cu}(\mathrm{EAA})_{2}(66 \mathrm{mg}, 0.20 \mathrm{mmol}, 0.25$ equiv) and pivalic acid ( $84 \mathrm{mg}, 0.82 \mathrm{mmol}, 1.0$ equiv) for 18 hours to yield 6-bromo- $N, N$-diethyl-1 H-benzo[d] imidazol-2-amine (22) as an off-white solid. (159 mg, 0.59 $\mathrm{mmol}, 74 \%)$

Melting point: $190-192{ }^{\circ} \mathrm{C}$ FTIR $v_{\max } / \mathrm{cm}^{-1} 2971,2929,1625,1560,1463 .{ }^{1} \mathrm{H}$ NMR $\left(400 \mathrm{MHz}, \mathrm{METHANOL-} \mathrm{d}_{4}\right) \delta \mathrm{ppm}$ $1.27(6 \mathrm{H}, \mathrm{t}, \mathrm{J}=7.1 \mathrm{~Hz}), 3.54(4 \mathrm{H}, \mathrm{q}, J=7.1 \mathrm{~Hz}), 7.04-7.13(2 \mathrm{H}, \mathrm{m}), 7.33(1 \mathrm{H}, \mathrm{d}, J=1.0 \mathrm{~Hz}){ }^{13} \mathrm{C}\left\{{ }^{1} \mathrm{H}\right\} \mathrm{NMR}(101 \mathrm{MHz}$, METHANOL-d 4 ) $\delta$ ppm 12.2, 42.7, 111.8, 112.2, 114.3, 122.2, 155.7 Two signals missing from spectra. HRMS (ESI Orbitrap) $\mathrm{m} / \mathrm{z}:[\mathrm{M}+\mathrm{H}]^{+}$Calcd for $\mathrm{C}_{11} \mathrm{H}_{15}{ }^{79} \mathrm{BrN}_{3}[\mathrm{M}+\mathrm{H}]^{+} 268.0444$, found $[\mathrm{M}+\mathrm{H}]^{+} 268.0445$.

\section{4-(6-bromo-1H-benzo[d]imidazol-2-yl)morpholine (25).}

Using general procedure 2 for benzimidazole formation was performed with $\mathrm{N}$-(4-bromophenyl)morpholine-4carboximidamide (63) (269 mg, $0.95 \mathrm{mmol}), \mathrm{Cu}(\mathrm{EAA})_{2}(78 \mathrm{mg}, 0.24 \mathrm{mmol}, 0.26$ equiv) and pivalic acid (99 $\mathrm{mg}, 0.97$ mmol, 1.0 equiv) for 21 hours to yield (25) as a brown solid. (157 mg, $0.56 \mathrm{mmol}, 59 \%$ )

Melting point: $235-236{ }^{\circ} \mathrm{C}$ FTIR $v_{\max } / \mathrm{cm}^{-1} 3476$ (br), 2976, 2842, 1626, 1557, 1441. ${ }^{1} \mathrm{H}$ NMR $(400 \mathrm{MHz}, \mathrm{METHANOL-}$ $\left.d_{4}\right) \delta$ ppm $3.48-3.55(4 \mathrm{H}, \mathrm{m}), 3.79-3.87(4 \mathrm{H}, \mathrm{m}), 7.09-7.19(2 \mathrm{H}, \mathrm{m}), 7.39\left(1 \mathrm{H}\right.$, app. s) ${ }^{13} \mathrm{C}\left\{{ }^{1} \mathrm{H}\right\} \mathrm{NMR}(101 \mathrm{MHz}$, CHLOROFORM-d) $\delta \mathrm{ppm} 46.6,66.1,113.8,123.9,156.4 .4$ signals are missing from the spectra, presumably the quaternary carbons. HRMS (ESI Orbitrap) $\mathrm{m} / \mathrm{z}$ : $[\mathrm{M}+\mathrm{H}]^{+}$Calcd for $\mathrm{C}_{11} \mathrm{H}_{13} \mathrm{BrN}_{3} \mathrm{O}[\mathrm{M}+\mathrm{H}]^{+} 282.0237$, found $[\mathrm{M}+\mathrm{H}]^{+}$ 282.0233.

\section{Emedastine synthesis}

\section{4-cyano-1,4-diazepane-1-carboxylate (45).}

To an ice-cooled solution of cyanogen bromide $(3.147 \mathrm{~g}, 29.7 \mathrm{mmol}, 1$ equiv) in chloroform $(10 \mathrm{~mL})$ under a nitrogen atmosphere was added tert-butyl 1,4-diazepane-1-carboxylate $(6.17 \mathrm{~g}, 30.8 \mathrm{mmol}, 1.05$ equiv) and diisopropylethylamine $(4.00 \mathrm{~g}, 30.9 \mathrm{mmol}, 1.05$ equiv) both as a solution in chloroform $(20 \mathrm{~mL})$. The reaction was slowly allowed to warm to rt. After $4 \mathrm{~h}$, the reaction was quenched with $2 \mathrm{M} \mathrm{NaOH}(50 \mathrm{~mL})$ and extracted with $\mathrm{CH}_{2} \mathrm{Cl}_{2}$ $(3 \times 40 \mathrm{~mL})$. The combined organic extracts were dried over anhydrous $\mathrm{MgSO}_{4}$, concentrated in vacuo and purified by chromatography ( $20 \%$ ethyl acetate in heptane) to yield 45 as a colourless oil ( $4.668 \mathrm{~g}, 20.7 \mathrm{mmol}, 70 \%)$.

${ }^{1} \mathrm{H}$ NMR (400 MHz, CHLOROFORM-d) $\delta$ ppm $3.34-3.48(\mathrm{~m}, 4 \mathrm{H}), 3.19-3.25(\mathrm{~m}, 2 \mathrm{H}), 3.12-3.18(\mathrm{~m}, 2 \mathrm{H}), 1.79$ - 1.91 (m, $2 \mathrm{H}$ ), 1.37 (s, $9 \mathrm{H}) .{ }^{13} \mathrm{C}$ NMR (101 MHz, CHLOROFORM-d) $\delta$ ppm 27.6, 28.3, 46.0, 47.5, 50.3, 52.0, 80.1, $117.7,154.6$. Observed as a mixture of rotomers. The spectroscopic data is in agreement with those previously reported ${ }^{\beta 2}$

\section{Tert-butyl4-(N'-phenylcarbamimidoyl)-1,4-diazepane-1 carboxylate (46).}

To a stirred suspension of $60 \%$ sodium hydride $(0.620 \mathrm{~g}, 15.5 \mathrm{mmol}, 1.1$ equiv) in DMSO $(10 \mathrm{~mL})$ was added aniline (1.33 g, $14.3 \mathrm{mmol}, 1$ equiv) as a solution in DMSO $(9 \mathrm{~mL})$ dropwise. After 15 minutes, tert-butyl 4-cyano-1,4diazepane-1-carboxylate $45(3.00 \mathrm{~g}, 13.3 \mathrm{mmol}, 0.93$ equiv) was added as a solution in DMSO (10 mL) and the reaction stirred at room temperature for 24 hours, at which point a further portion of tert-butyl 4-cyano-1,4-diazepane1-carboxylate 45 ( $0.500 \mathrm{~g}, 2.2 \mathrm{mmol}, 0.16$ equiv) was added as a solution in DMSO ( $5 \mathrm{~mL})$. After a further 60 minutes, the reaction was quenched with water $(50 \mathrm{~mL})$ and extracted into tBME $(3 \times 50 \mathrm{~mL})$. The combined organic extracts were washed with water $(3 \times 50 \mathrm{~mL})$ and brine $(1 \times 30 \mathrm{~mL})$ before being purified by chromatography (SNAP Ultra, 
$50 \%$ EtOAc/Heptane $\rightarrow$ EtOAc with $2 \%$ triethylamine in the EtOAc portions) to yield an off white solid ( $3.17 \mathrm{~g}, 9.6$ $\mathrm{mmol}, 96.7 \%$ purity by HPLC analysis, $67.4 \%$ based on aniline). The off-white solid was recrystallised from tBME to yield $2.65 \mathrm{~g}$ of analytically pure material of $>99 \%$ purity by HPLC analysis which was used in the subsequent dehydrogenative cyclisation.

Melting point: $107-108{ }^{\circ} \mathrm{C}$ FTIR $v_{\max } / \mathrm{cm}^{-1} 3485,3395,2979,1680,1618,1575 .{ }^{1} \mathrm{H}$ NMR $\left(400 \mathrm{MHz}, \mathrm{METHANOL-} \mathrm{d}_{4}\right)$ $\delta$ ppm $1.52(9 \mathrm{H}, \mathrm{s}), 1.87-1.98(2 \mathrm{H}, \mathrm{m}), 3.49(2 \mathrm{H}, \mathrm{t}, \mathrm{J}=5.9 \mathrm{~Hz}), 3.55(2 \mathrm{H}, \mathrm{t}, \mathrm{J}=5.9 \mathrm{~Hz}), 3.60-3.67(4 \mathrm{H}, \mathrm{m}), 6.91$ $(2 \mathrm{H}, \mathrm{d}, \mathrm{J}=7.6 \mathrm{~Hz}), 7.01(1 \mathrm{H}, \mathrm{t}, \mathrm{J}=7.6 \mathrm{~Hz}), 7.29(2 \mathrm{H}, \mathrm{t}, \mathrm{J}=7.6 \mathrm{~Hz})$ Observed as a mixture of rotomers. ${ }^{13} \mathrm{C}\left\{{ }^{1} \mathrm{H}\right\} \mathrm{NMR}$ $\left(101 \mathrm{MHz}, \mathrm{DMSO}-d_{6}\right) \delta$ ppm 27.1, 28.6, 45.8, 46.2, 46.6, 46.8, 47.1, 47.4, 48.2, 48.6, 78.8, 78.9, 120.5, 123.5, 129.3, 151.2, 151.3, 151.9, 154.9. HRMS (ESI Orbitrap) $\mathrm{m} / \mathrm{z}$ : $[\mathrm{M}+\mathrm{H}]^{+}$Calcd for $\mathrm{C}_{17} \mathrm{H}_{27} \mathrm{~N}_{4} \mathrm{O}_{2}[\mathrm{M}+\mathrm{H}]^{+} 319.2129$ found $[\mathrm{M}+$ $\mathrm{H}]^{+} 319.2116$.

\section{Tert-butyl 4-(1H-benzo[d]imidazol-2-yl)-1,4-diazepane-1-carboxylate (47).}

To a round bottom flask was added tert-butyl 4-( $N$-phenylcarbamimidoyl)-1,4-diazepane-1-carboxylate (46) (2415 $\mathrm{mg}, 7.6 \mathrm{mmol}, 1$ equiv), $\mathrm{Cu}(\mathrm{EAA})_{2}$ (303 mg, $0.94 \mathrm{mmol}, 0.12$ equiv) and pivalic acid ( $776 \mathrm{mg}, 7.6 \mathrm{mmol}, 1.03$ equiv) prior to the addition of a stir bar and sulfolane $(20 \mathrm{~mL})$. The reaction was heated to $100^{\circ} \mathrm{C}$ for 30 hours at which point it was then cooled to room temperature. The resultant solid was suspended between water $(100 \mathrm{~mL})$ and tBME $(100$ $\mathrm{mL}$ ) before addition of $\mathrm{EDTA}_{(\mathrm{aq})}(20 \mathrm{~mL}, 0.1 \mathrm{M})$. The organic portion was separated and the aqueous washed with further tBME $(3 \times 75 \mathrm{~mL})$. The resultant aqueous solution $(\sim 100 \mathrm{~mL})$ was then saturated with $\mathrm{NaCl}$ and then extracted with tBME $(1 \times 50 \mathrm{~mL})$. The combined organic extracts were then washed with water $(5 \times 50 \mathrm{~mL})$, the water washes back-extracted with tBME $(2 \times 50 \mathrm{~mL})$ and the combined organic portions washed with brine. The brown organic solution was reduced in volume to $\sim 30 \mathrm{~mL}$ at which point a white solid precipitated. The mixture was cooled in an ice bath and the solid was filtered to yield a white solid $(1.410 \mathrm{~g})$. The organic solution was then purified by chromatography (SNAP Ultra, $0-3 \% \mathrm{MeOH} / \mathrm{CH}_{2} \mathrm{Cl}_{2}$ ) to yield $305 \mathrm{mg}$ of a white solid. The two solids were combined, homogenised with $\mathrm{MeOH}$ and evaporated to give tert-butyl 4-(1H-benzo[d]imidazol-2-yl)-1,4-diazepane-1carboxylate (47) as a white solid $(1.715 \mathrm{~g}, 5.4 \mathrm{mmol}, 71 \%)$ Melting point: $219-220{ }^{\circ} \mathrm{C}$. FTIR $\mathrm{v}_{\max } / \mathrm{cm}^{-1} 2970$ (br), 1686, 1626, 1597, 1566, 1461. ${ }^{1} \mathrm{H}$ NMR (400 MHz, METHANOL-d 4$) \delta \mathrm{ppm} 1.30(5 \mathrm{H}, \mathrm{s}), 1.38(4 \mathrm{H}, \mathrm{s}), 1.88-2.08$ $(2 \mathrm{H}, \mathrm{m}), 3.38-3.48(2 \mathrm{H}, \mathrm{m}), 3.63-3.81(6 \mathrm{H}, \mathrm{m}), 6.95-7.02(2 \mathrm{H}, \mathrm{m}), 7.19-7.26(2 \mathrm{H}, \mathrm{m})$ Observed as a mixture of rotomers. ${ }^{13} \mathrm{C}\left\{{ }^{1} \mathrm{H}\right\}$ NMR $\left(101 \mathrm{MHz}\right.$, METHANOL- $\left.d_{4}\right) \delta$ ppm 22.3, 26.1, 26.2, 27.0, 27.2, 27.3, 45.5, 45.9, 46.2, 46.5, 47.9, 48.3, 48.6, 50.6, 79.8, 111.6, 119.9, 154.7, 155.4, 155.6 HRMS (ESI Orbitrap) m/z: [M + H]+ Calcd for $\mathrm{C}_{17} \mathrm{H}_{25} \mathrm{~N}_{4} \mathrm{O}_{2}[\mathrm{M}+\mathrm{H}]^{+} 317.1972$, found $[\mathrm{M}+\mathrm{H}]^{+} 317.1867$.

\section{Tert-butyl 4-(1-(2-ethoxyethyl)-1H-benzo[d]imidazol-2-yl)-1,4-diazepane-1-carboxylate (49).}

To a suspension of tert-butyl 4-(1H-benzo[d]imidazol-2-yl)-1,4-diazepane-1-carboxylate (47) (1.320 g, $4.2 \mathrm{mmol}, 1.0$ equiv) in THF (30 mL) was added $60 \%$ sodium hydride suspension $(0.220 \mathrm{~g}, 5.5 \mathrm{mmol}, 1.3$ equiv) in 5 separate portions over a period of 15 minutes. The resultant solution was stirred for 15 minutes before addition of 1-(2iodoethoxy)ethane (48) (1.155 g, $5.8 \mathrm{mmol}, 1.4$ equiv) as a solution in THF (2 mL). The reaction was heated to reflux for 18 hours under nitrogen before a second addition of 1-(2-iodoethoxy)ethane (48) $(0.162 \mathrm{~g}, 0.81 \mathrm{mmol}, 0.2$ equiv). After a further 60 minutes the reaction was cooled to room temperature, quenched with water and the volatiles removed under reduced pressure. The resultant aqueous was extracted into $\mathrm{CH}_{2} \mathrm{Cl}_{2}(3 \times 30 \mathrm{~mL})$, the combined organic portions washed with brine, dried over a hydrophobic frit and concentrated in vacuo. The crude material was purified by chromatography (SNAP Ultra, 40\% EtOAc/heptane $\rightarrow$ EtOAc) to yield tert-butyl 4-(1-(2-ethoxyethyl)-1Hbenzo[d] imidazol-2-yl)-1,4-diazepane-1-carboxylate (49) as a colourless oil (1.443 g, $3.7 \mathrm{mmol}, 89 \%)$

FTIR $V_{\max } / \mathrm{cm}^{-1}$ 2971, 2871, 1688, 1527, 1436, 1408. ${ }^{1 \mathrm{H}}$ NMR $(400 \mathrm{MHz}$, CHLOROFORM-d) $\delta \mathrm{ppm} 1.16(3 \mathrm{H}, \mathrm{t}$, $\mathrm{J}=6.9 \mathrm{~Hz}), 1.49(4.5 \mathrm{H}, \mathrm{s}), 1.50(4.5 \mathrm{H}, \mathrm{s}) 1.91-2.08(2 \mathrm{H}, \mathrm{m}), 3.47(3 \mathrm{H}, \mathrm{q}, \mathrm{J}=6.9 \mathrm{~Hz}), 3.53-3.64(5 \mathrm{H}, \mathrm{m}), 3.64-$ $3.75(2 \mathrm{H}, \mathrm{m}), 3.81(2 \mathrm{H}, \mathrm{t}, \mathrm{J}=5.8 \mathrm{~Hz}), 4.21(2 \mathrm{H}, \mathrm{t}, \mathrm{J}=5.8 \mathrm{~Hz}), 7.10-7.23(2 \mathrm{H}, \mathrm{m}), 7.26-7.33(1 \mathrm{H}, \mathrm{m}), 7.52-7.61$ $(1 \mathrm{H}, \mathrm{m})$ Observed as a mixture of rotomers. ${ }^{13} \mathrm{C}\left\{{ }^{1} \mathrm{H}\right\}$ NMR $(101 \mathrm{MHz}$, CHLOROFORM-d) $\delta \mathrm{ppm} 15.1,28.2,28.5$, 28.6, 44.6, 45.4, 44.7, 45.9, 47.7, 48.3, 52.7, 53.1, 54.2, 54.5, 66.9, 68.2, 68.3, 79.5, 79.6, 109.3, 117.8, 117.8, 121.0, 121.1, 121.8, 135.3, 135.4, 141.5, 141.6, 155.3, 155.5, 158.8, 159. HRMS (ESI Orbitrap) m/z: $[\mathrm{M}+\mathrm{H}]^{+}$Calcd for $\mathrm{C}_{21} \mathrm{H}_{33} \mathrm{~N}_{4} \mathrm{O}_{3}[\mathrm{M}+\mathrm{H}]^{+} 389.2547$, found $[\mathrm{M}+\mathrm{H}]^{+} 389.2534$ 


\section{2-(1,4-Diazepan-1-yl)-1-(2-ethoxyethyl)-1H-benzo[d]imidazole (50).}

To a dry round bottomed flask containing tert-butyl 4-(1-(2-ethoxyethyl)-1H-benzo[d]imidazol-2-yl)-1,4-diazepane-1carboxylate (50) (1.397 g, $3.6 \mathrm{mmol}, 1.0$ equiv) was added $\mathrm{HCl}$ as a solution in EtOAc (1 M, $20 \mathrm{~mL}, 20 \mathrm{mmol}, 5.6$ equiv). The reaction was stirred at room temperature for 64 hours before quenching with saturated sodium bicarbonate $(50 \mathrm{~mL})$ and diluting with $\mathrm{CH}_{2} \mathrm{Cl}_{2}(30 \mathrm{~mL})$. The organic layer was separated and the resultant aqueous portion washed a further 2 times with $\mathrm{CH}_{2} \mathrm{Cl}_{2}(2 \times 10 \mathrm{~mL})$. The combined organics were washed with brine $(10 \mathrm{~mL})$, dried over a hydrophobic frit and concentrated in vacuo to yield 2-(1,4-diazepan-1-yl)-1-(2-ethoxyethyl)-1Hbenzo[d]imidazole (50a) as a pale-yellow oil (962 mg, $3.3 \mathrm{mmol}, 93 \%)$.

FTIR $v_{\max } / \mathrm{cm}^{-1} 3400$ (br), 2970, 2872, 1528, 1464, 1408, 1285. ${ }^{1} \mathrm{H}$ NMR $(400 \mathrm{MHz}$, CHLOROFORM-d) $\delta$ ppm 1.15 $(3 \mathrm{H}, \mathrm{t}, J=7.0 \mathrm{~Hz}), 1.94(2 \mathrm{H}$, quin, $J=5.9 \mathrm{~Hz}), 2.30(1 \mathrm{H}, \mathrm{br} . \mathrm{s}), 3.04-3.08(2 \mathrm{H}, \mathrm{m}), 3.10-3.15(2 \mathrm{H}, \mathrm{m}), 3.47(2 \mathrm{H}$, q, J=7.0 Hz), $3.59-3.64(4 \mathrm{H}, \mathrm{m}), 3.79(2 \mathrm{H}, \mathrm{t}, \mathrm{J}=6.0 \mathrm{~Hz}), 4.20(2 \mathrm{H}, \mathrm{t}, \mathrm{J}=6.0 \mathrm{~Hz}), 7.08-7.20(2 \mathrm{H}, \mathrm{m}), 7.24-7.29$ $(1 \mathrm{H}, \mathrm{m}), 7.52-7.57(1 \mathrm{H}, \mathrm{m}){ }^{13} \mathrm{C}\left\{{ }^{1} \mathrm{H}\right\}$ NMR $(101 \mathrm{MHz}$, CHLOROFORM-d) $\delta \mathrm{ppm} 15.1,31.1,44.7,48.2,49.8,52.7$, 55.8, 66.9, 68.3, 109.1, 117.6, 120.8, 121.7, 135.5, 141.7, 159.2 HRMS (ESI Orbitrap) m/z: [M + H]+ Calcd for $\mathrm{C}_{16} \mathrm{H}_{25} \mathrm{~N}_{4} \mathrm{O}[\mathrm{M}+\mathrm{H}]^{+} 289.2023$, found $[\mathrm{M}+\mathrm{H}]^{+} 289.2012$ The spectroscopic data is in agreement with those previously reported ${ }^{33}$

\section{2-(4-Methyl-1,4-diazepan-1-yl)-1-(2-ethoxyethyl)-1H-benzo[d]imidazole, Emedastine (2).}

To a dry round bottomed flask containing 2-(1,4-diazepan-1-yl)-1-(2-ethoxyethyl)-1H-benzo[d]imidazole (50) (915 $\mathrm{mg}, 3.2 \mathrm{mmol}, 1.0$ equiv) was added formaldehyde (13.0 mL, $37 \mathrm{wt} \%$ aq, $175.0 \mathrm{mmol}, 55$ equiv) and formic acid $\left(1.80 \mathrm{~g}, 1.50 \mathrm{~mL}, 39.1 \mathrm{mmol}, 12.3\right.$ equiv). The reaction was stirred and heated to $80^{\circ} \mathrm{C}$ for 30 minutes before diluting into water $(50 \mathrm{~mL})$, basifying with $\mathrm{NaOH}$ to $\mathrm{pH} 10\left(2 \mathrm{M}\right.$ aq) and extracting with $\mathrm{CH}_{2} \mathrm{Cl}_{2}(5 \times 40 \mathrm{~mL})$. The combined organic extracts were washed with brine $(20 \mathrm{~mL})$, dried over a hydrophobic frit and concentrated in vacuo to yield an orange oil, which was purified by chromatography $\left(0-10 \% \mathrm{MeOH} / \mathrm{CH}_{2} \mathrm{Cl}_{2} \mathrm{w} / 1 \% \mathrm{Et}_{3} \mathrm{~N}\right.$ in the $\mathrm{CH}_{2} \mathrm{Cl}_{2}$ portion) to yield 2-(4-methyl-1,4-diazepan-1-yl)-1-(2-ethoxyethyl)-1H-benzo[d]imidazole (Emedastine, 2) as a pale yellow oil (824 mg, $2.7 \mathrm{mmol}, 86 \%)$.

FTIR $v_{\max } / \mathrm{cm}^{-1}$ 2910, 2803, 1611, 1532, 1470. ${ }^{1} \mathrm{H}$ NMR (400 MHz, CHLOROFORM-d) $\delta \mathrm{ppm} 1.17$ (3 H, t, J=7.0 Hz), 2.06 (2 H, br. s.), $2.45(3 \mathrm{H}, \mathrm{s}), 2.79(4 \mathrm{H}, \mathrm{m}), 3.48(2 \mathrm{H}, \mathrm{q}, \mathrm{J}=6.9 \mathrm{~Hz}), 3.67(2 \mathrm{H}, \mathrm{t}, \mathrm{J}=6.2 \mathrm{~Hz}), 3.71(2 \mathrm{H}, \mathrm{m}), 3.80(2$ $\mathrm{H}, \mathrm{t}, \mathrm{J}=6.0 \mathrm{~Hz}), 4.21(2 \mathrm{H}, \mathrm{t}, \mathrm{J}=6.0 \mathrm{~Hz}), 7.15(2 \mathrm{H}, \mathrm{m}), 7.26(1 \mathrm{H}, \mathrm{s}) 7.55(1 \mathrm{H}, \mathrm{m}){ }^{13} \mathrm{C}\left\{{ }^{1} \mathrm{H}\right\} \mathrm{NMR}(101 \mathrm{MHz}$, CHLOROFORM-d) $\delta$ ppm 15.1, 28.0, 44.9, 46.8, 51.9, 57.6, 58.6, 66.9, 68.3, 77.2, 109.1, 110.0, 117.5, 120.7, 121.7, 135.6, 141.8 HRMS (ESI Orbitrap) m/z: $[\mathrm{M}+\mathrm{H}]^{+}$Calcd for $\mathrm{C}_{17} \mathrm{H}_{27} \mathrm{~N}_{4} \mathrm{O}[\mathrm{M}+\mathrm{H}]^{+} 303.2179$, found $[\mathrm{M}+\mathrm{H}]^{+} 303.2173$ Spectroscopic data is in agreement with the literature. ${ }^{34}$

\section{Conflicts of interest}

There are no conflicts to declare.

\section{Corresponding author}

*Email: peter.r.clark@gsk.com

\section{Acknowledgements}

We thank GlaxoSmithKline (GSK) for a PhD studentship (PRC), for financial support and chemical resources. We thank the EPSRC for funding via Prosperity Partnership EP/S035990/1. We thank J. McKnight and D. Valette for initial scoping, S. Davies for DoE, P. Rushworth \& K. Wheelhouse for screening.

\section{References}


(1) Davies, H. M. L.; Morton, D. ACS. Cent. Sci. 2017, 3, 936.

(2) Morel, B.; Franck, P.; Bidange, J.; Sergeyev, S.; Smith, D. A.; Moseley, J. D.; Maes, B. U. W. Chem. Sus. Chem. 2017, 10, 624 .

(3) Xie, Z.; Cai, Y.; Hu, H.; Lin, C.; Jiang, J.; Chen, Z.; Wang, L.; Pan, Y. Org. Lett. 2013, 15, 4600.

(4) Fan, S.; Chen, Z.; Zhang, X. Org. Lett. 2012, 14, 4950.

(5) Ueda, S.; Nagasawa, H. J. Org. Chem. 2009, 74, 4272.

(6) Gavriilidis, A.; Constantinou, A.; Hellgardt, K.; Hii, K. K.; Hutchings, G. J.; Brett, G. L.; Kuhn, S.; Marsden, S. P. React. Chem. Eng. 2016, 1, 595.

(7) Jiang, H.; Yu, W.; Tang, X.; Li, J.; Wu, W. J. Org. Chem. 2017.

(8) Wang, D.; Weinstein, A. B.; White, P. B.; Stahl, S. S. Chem. Rev. 2017.

(9) Bartels, B.; Bolas, C. G.; Cueni, P.; Fantasia, S.; Gaeng, N.; Trita, A. S. J. Org. Chem. 2015, 80, 1249.

(10) Brasche, G.; Buchwald, S. L. Angew. Chem. Int. Ed. 2008, 47, 1932.

(11) Özden, S.; Atabey, D.; Yıldız, S.; Göker, H. Eur. J. Med. Chem. 2008, 43, 1390.

(12) Zhang, G.; Ren, P.; Gray, N. S.; Sim, T.; Liu, Y.; Wang, X.; Che, J.; Tian, S.-S.; Sandberg, M. L.; Spalding, T. A.; Romeo, R.; Iskandar, M.; Chow, D.; Martin Seidel, H.; Karanewsky, D. S.; He, Y. Bioorg. Med. Chem. Lett. 2008, $18,5618$.

(13) Kim, R. M.; Chang, J.; Lins, A. R.; Brady, E.; Candelore, M. R.; Dallas-Yang, Q.; Ding, V.; Dragovic, J.; lliff, S.; Jiang, G.; Mock, S.; Qureshi, S.; Saperstein, R.; Szalkowski, D.; Tamvakopoulos, C.; Tota, L.; Wright, M.; Yang, X.; Tata, J. R.; Chapman, K.; Zhang, B. B.; Parmee, E. R. Bioorg. Med. Chem. Lett. 2008, 18, 3701.

(14) Bonfanti, J.-F.; Meyer, C.; Doublet, F.; Fortin, J.; Muller, P.; Queguiner, L.; Gevers, T.; Janssens, P.; Szel, H.; Willebrords, R.; Timmerman, P.; Wuyts, K.; van Remoortere, P.; Janssens, F.; Wigerinck, P.; Andries, K. J. Med. Chem. 2008, 51, 875 .

(15) Shao, B.; Huang, J.; Sun, Q.; Valenzano, K. J.; Schmid, L.; Nolan, S. Bioorg. Med. Chem. Lett. 2005, 15, 719.

(16) Ognyanov, V. I.; Balan, C.; Bannon, A. W.; Bo, Y.; Dominguez, C.; Fotsch, C.; Gore, V. K.; Klionsky, L.; Ma, V. V.; Qian, Y.-X.; Tamir, R.; Wang, X.; Xi, N.; Xu, S.; Zhu, D.; Gavva, N. R.; Treanor, J. J. S.; Norman, M. H. J. Med. Chem. 2006, 49, 3719.

(17) Murphy, D. B.; Musco, J. J. Org. Chem. 1971, 36, 3469.

(18) Barrett, I. C.; Kerr, M. A. Tetrahedron Lett. 1999, 40, 2439.

(19) Janssens, F.; Torremans, J.; Janssen, M.; Stokbroekx, R. A.; Luyckx, M.; Janssen, P. A. J. J. Med. Chem. 1985, 28, 1943.

(20) Hasegawa, M.; Nishigaki, N.; Washio, Y.; Kano, K.; Harris, P. A.; Sato, H.; Mori, I.; West, R. I.; Shibahara, M.; Toyoda, H.; Wang, L.; Nolte, R. T.; Veal, J. M.; Cheung, M. J. Med. Chem. 2007, 50, 4453.

(21) Smiley, R. A. Ullmann's Encyclopedia of Industrial Chemistry 2000.

(22) Deng, X.; McAllister, H.; Mani, N. S. J. Org. Chem. 2009, 74, 5742.

(23) Chi, Y.; Zhang, W.-X.; Xi, Z. Org. Lett. 2014, 16, 6274. 
(24) Sambiagio, C.; Marsden, S. P.; Blacker, A. J.; McGowan, P. C. Chem. Soc. Rev. 2014, 43, 3525.

(25) Evindar, G.; Batey, R. A. Org. Lett. 2003, 5, 133.

(26) Tang, S.; Gong, T.; Fu, Y. Sci. Chin. Chem. 2013, 56, 619.

(27) F. Ke, C. L., J. Xu, X. Chen, S. Xu, Y. Xu China, 2018; Vol. CN107954939.

(28) Montalvão, S.; Leino, T. O.; Kiuru, P. S.; Lillsunde, K.-E.; Yli-Kauhaluoma, J.; Tammela, P. Archiv der Pharmazie 2016, 349, 137.

(29) J. Diaz, D. H., J. Speake,C. Zhang, W. Mills, P. Spearing, D. Cowan, G. Green. 2010; Vol. US222345.

(30) Joseph, L.; Albert, A. H. J. Het. Chem. 1966, 3, 107.

(31) Zhu, J.; Wu, C.-F.; Li, X.; Wu, G.-S.; Xie, S.; Hu, Q.-N.; Deng, Z.; Zhu, M. X.; Luo, H.-R.; Hong, X. Bioorg. Med. Chem. 2013, 21, 4218.

(32) Liang, H.; Bao, L.; Du, Y.; Zhang, Y.; Pang, S.; Sun, C. Synlett 2017, 28, 2675.

(33) lemura, R.; Hori, M.; Ohtaka, H. Chem. Pharm. Bull. 1989, 37, 962.

(34) R. lemura, T. K., F. Toshikazu, K. Ito, T. Nose, G. Tsukamoto 1982; Vol. US4430343. 